\title{
Fostering Powerful Use of Technology Through Instructional Coaching
}

Results from the Pilot Year of the Dynamic Learning Project

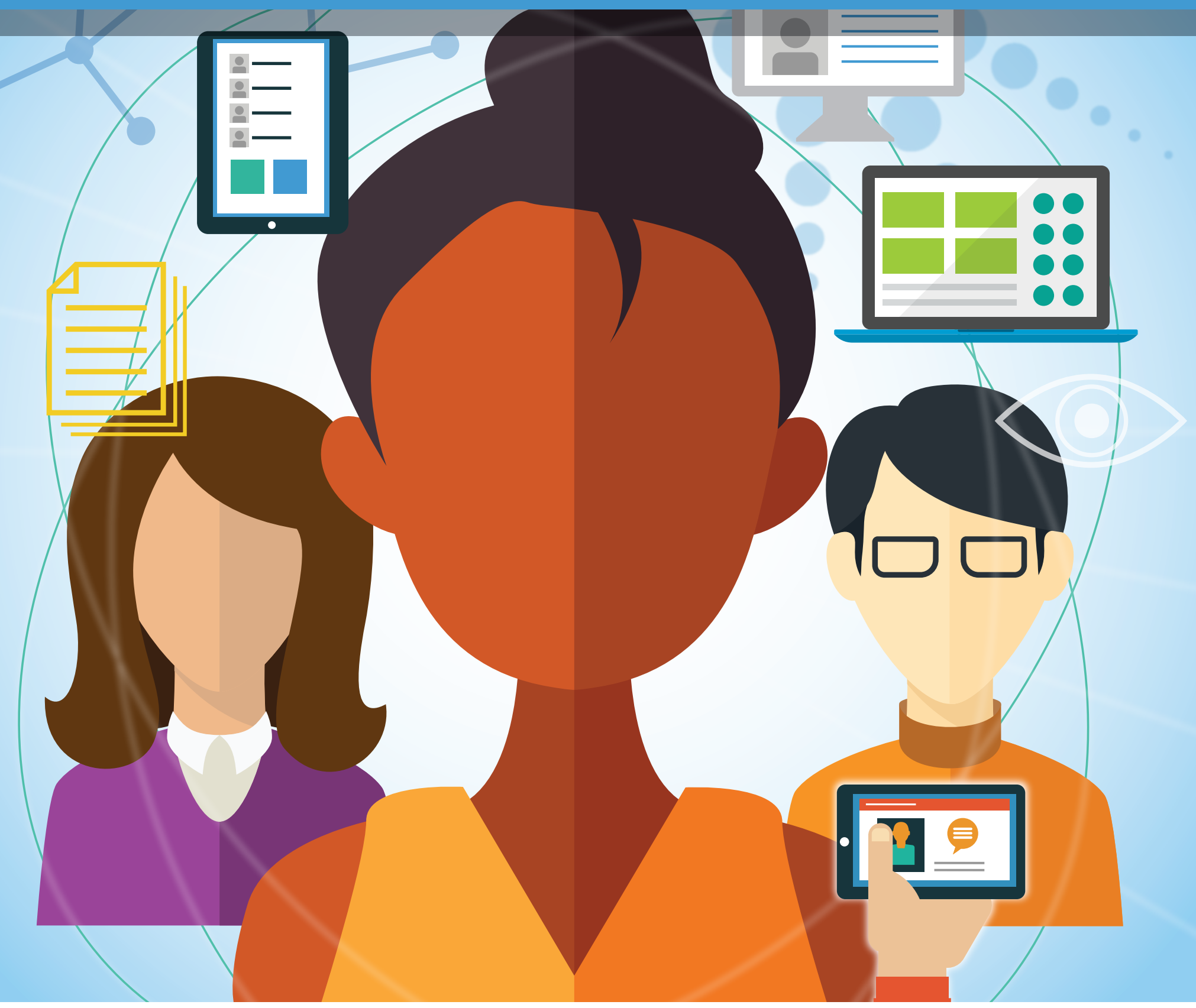

Authored by: Mahsa Bakhshaei, Angela Hardy, Aubrey Francisco, Sierra Noakes, and Judi Fusco 


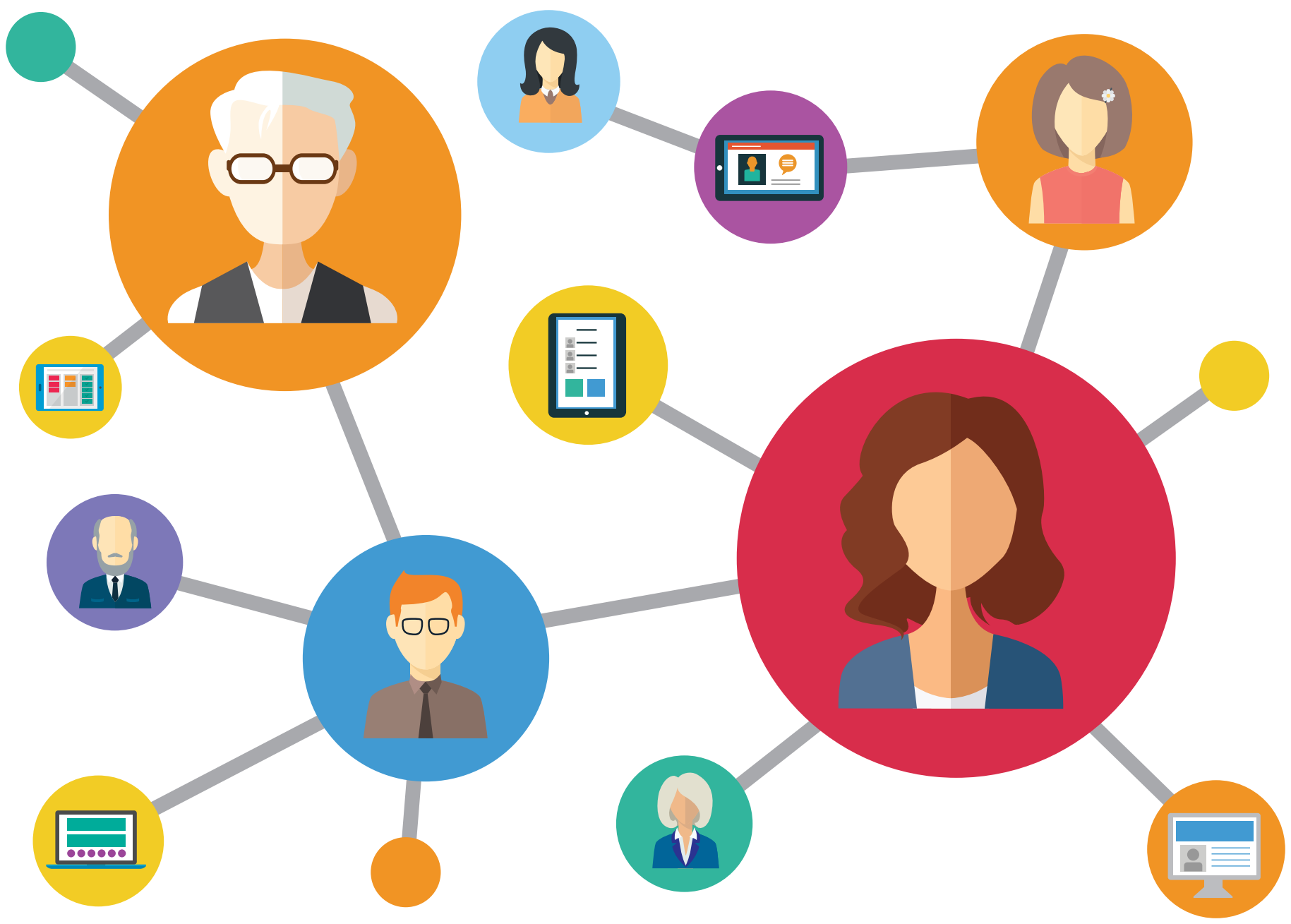

\section{CONTENTS}

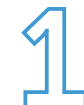

Executive Summary

45

Conclusions.

26

2 Introduction 


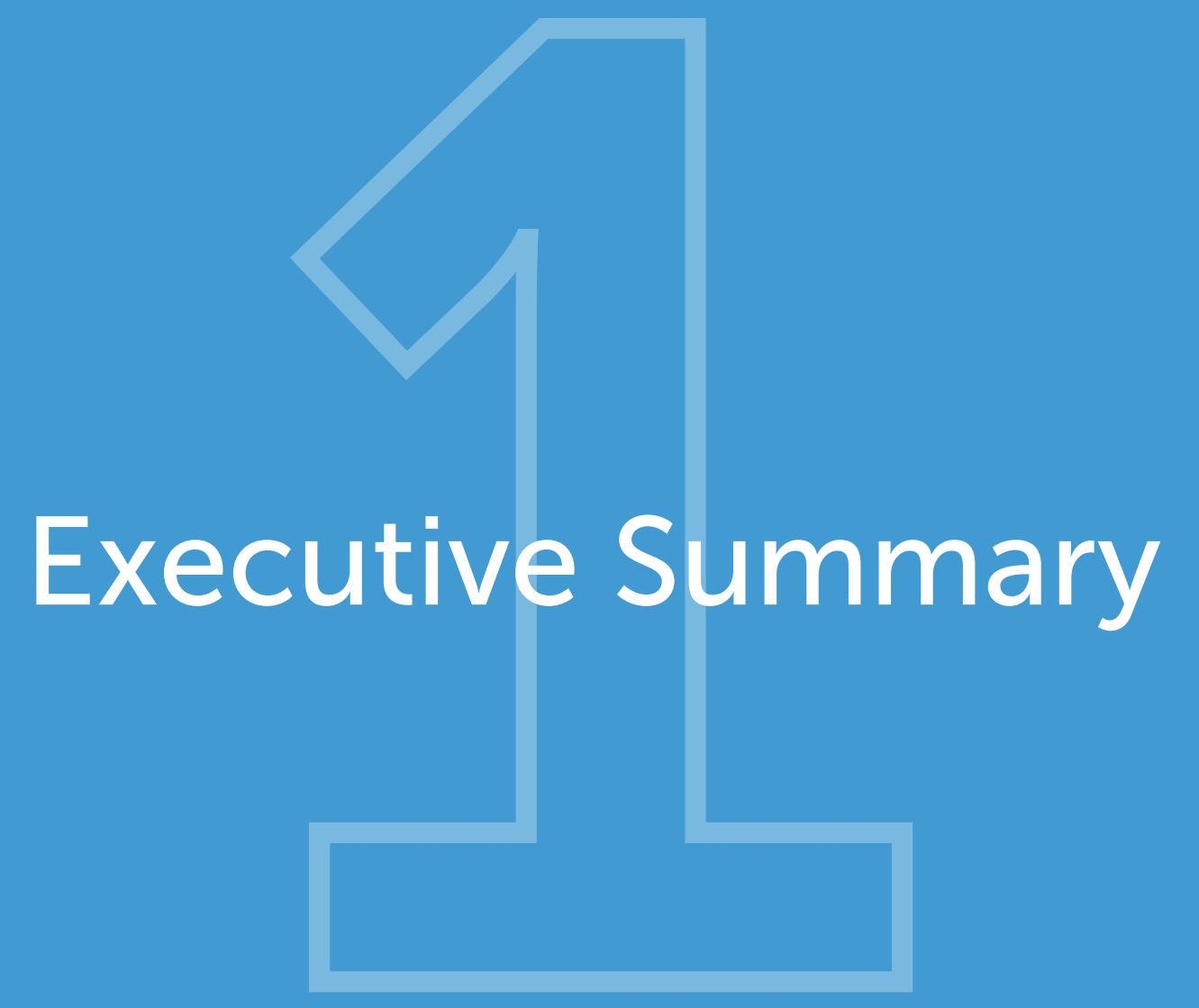




\section{EXECUTIVE SUMMARY}

The Dynamic Learning Project (DLP) seeks to improve educational equity and enhance student learning by supporting teachers with classroom coaching to better leverage technology in powerful and meaningful ways. While it seems like technology should be a tool for leveling the playing field at schools of differing socioeconomic and demographic populations, some schools and teachers require more support to conquer the learning curve
associated with how best to leverage technology for learning.

Research findings suggest that instructional technology coaching may be a critical lever in closing the gap in the usage of technology, sometimes referred to as the digital use divide (Ehsanipour \& Zaccarelli, 2017). The theory of change behind the DLP is that instructional coaching will drive increased student and teacher success through more effective use of technology.

Working with 50 schools having an average of 66 percent of students who qualify for free/reduced price lunch in 20 school districts across five states-Alabama, California, Pennsylvania, South Carolina, and Texas-we provided each school with a grant to support an onsite, full-time instructional technology coach (called a DLP coach) for one year.

DLP coaches provided individualized support to teachers over the course of four eight-week coaching cycles. During each cycle, coaches worked with each teacher to help them select, tackle, and then reflect upon a classroom challenge(s). The school-based coaches, as well as the principals, received sustained mentoring and ongoing Professional Development (PD) throughout the year, including participation in live events such as a Summer Institute and a regionally-based Winter Institute. Furthermore, they became members of the DLP Professional Learning Network (PLN). Over the course of the year, mentors served as accessible experts who could provide an outside perspective and personalized support to coaches, as well as to the principal at each school. School district staff also played key roles in the ongoing implementation of the pilot year.

If there is one takeaway from the pilot year of the

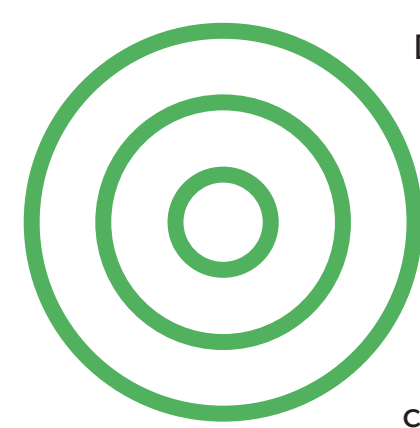
DLP, it is that district leaders, teachers, principals, and coaches believe that instructional technology coaching provides an engaging and impactful PD experience that helps close the digital use divide, and can ultimately increase student achievement.

Our data shows that after one year of working with their DLP coach, teachers are using technology more frequently and in more powerful ways. DLP teachers report significant increases in using technology for both teaching content and pedagogy-in other words, teachers are using technology to support what they are teaching, as well as how they are teaching it. At the 
end of the year, more than 80 percent of DLP teachers agreed that they have the ability to use technology in powerful ways when it comes to student collaboration, creativity, communication, critical thinking, agency, and that students are better at selecting appropriate technology tools.

By the end of the pilot year, coaches reported feeling significantly more confident in their own coaching skills and ability, attributing their growth to the ongoing mentorship and peer learning fostered by the DLP. Similarly, almost all principals reported high or extremely high levels of confidence in their leadership skills related to instructional coaching. Principals described the DLP as encouraging them to model risk-taking, experimentation, and continuous learning.
Importantly, this pilot year research helped us to further define the conditions necessary for a successful instructional technology coaching intervention. We identified six core attributes of a strong coaching model, and five key qualities of a successful coach. The six core attributes are: partnerships, personalization, voluntary nature, situated in school/classroom, non-evaluative, and sustained. The five key qualities are: relationship builder, insider, strong communicator, tech believer, and experienced teacher.

We know where we want to go-we envision a world in which all teachers and students have equitable access to technology, and all teachers and students equally benefit from all that technology has to offer. In this new world, taking the time to coach teachers in using technology is a crucial step for schools in moving to the next level. The DLP's pilot year results offer guidance for creating that equitable, opportunity-filled world. 


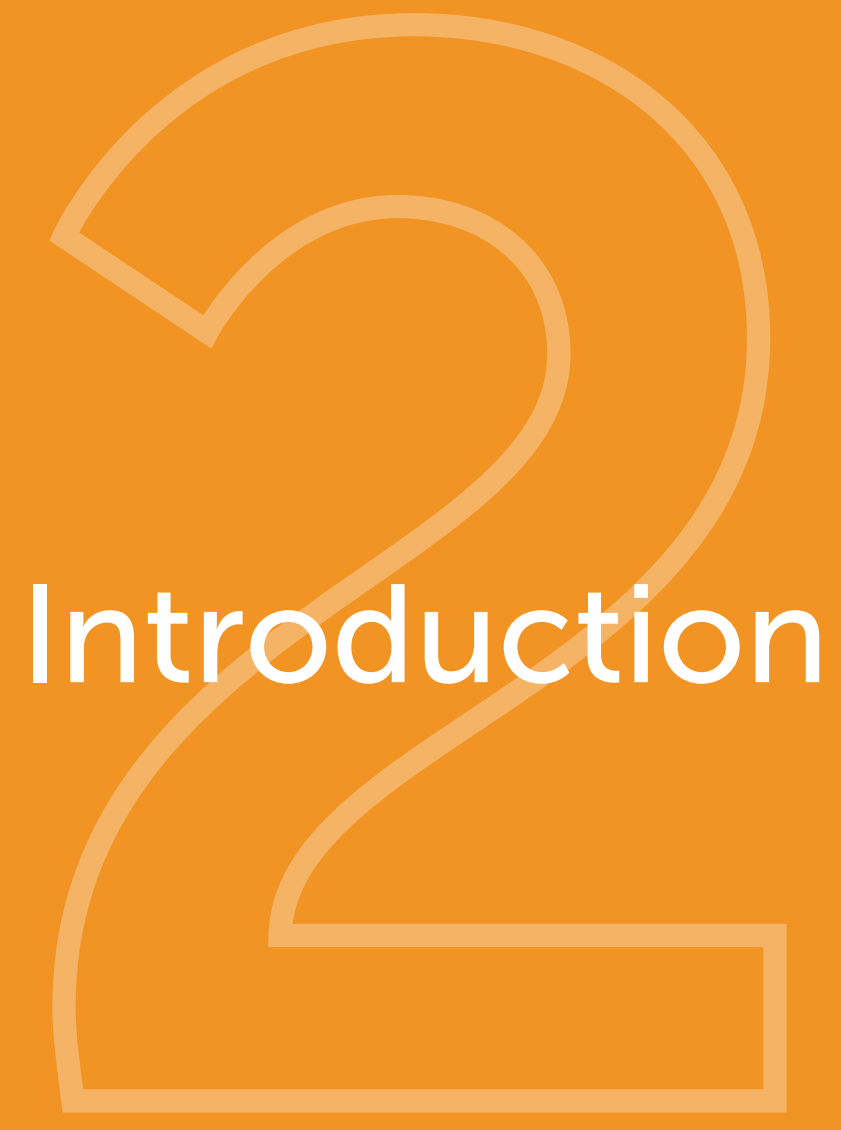


"In my years at [my school], I've never

seen any 'initiative' or 'project' so

wholly embraced by such a large (and

diverse) group of the faculty (...) there

is still so much to learn, so much

information to gain with another year in

the coaching position."

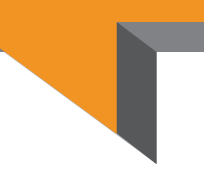

\section{INTRODUCTION}

After the first year of the Dynamic Learning Project (DLP), principals, teachers, coaches, and students are more engaged, more collaborative, and well on their way to experiencing a fundamental culture shift in their schools. Early research findings suggest the DLP is changing school culture through instructional coaching, revealing a critical lever in closing digital divides.

In the past 10 years, the first digital divide across U.S. public schools has narrowed significantly-more than 90 percent of schools now have access to the internet (Education Superhighway, 2018). At the same time, a new divide emerged-the digital use divide-which is fueled by major differences in how teachers and students use technology.

The aim of the Dynamic Learning Project is to increase educational equity and improve outcomes through an instructional coaching program designed to support teachers in using technology in powerful and impactful ways. To accomplish this, we need to recognize two important facts:

1. Many teachers do not have the training, experience, and resources to use technology in the most effective and innovative ways to advance student achievement, especially in low-income and underserved schools.

2. Almost half of U.S. teachers desire more training than they currently receive in using technology effectively (U.S. Department of Education, 2017).
Technology can be a transformational tool for teachers toward improving student learning, increasing student engagement, and driving school innovation. While it seems like technology should be a tool for leveling the playing field at schools of differing socioeconomic and demographic populations, some schools and teachers require more support to conquer the learning curve associated with how best to leverage technology for learning. As one group of leading researchers and educators said, "schools serving privileged students tend to use the same technologies in more progressive ways than schools serving less privileged students" (Reich \& Ito, 2017).

It's not enough to ensure that a school has access to the internet or devices. To achieve equity, some schools will require more support to conquer a learning curve associated with how to use technology to improve student outcomes.

\section{What are the goals behind the Dynamic Learning Project?}

The Dynamic Learning Project (DLP) seeks to improve educational equity and student learning by supporting 
teachers with classroom coaching to better leverage technology in powerful and meaningful ways.

We know where we want to go-we envision a world in which all teachers and students have equitable access to technology, and equally benefit from all that technology has to offer. But how do we get there?

Within schools, teachers are the greatest asset to student achievement (Darling-Hammond, 2000; Harris \& Sass, 2011). To enrich student learning, we must empower teachers. At the same time, technology can provide teachers with powerful ways to support student learning and provide meaningful and diverse learning experiences (DarlingHammond, Zielezinski \& Goldman, 2014).

We also know from the research that instructional coaching is a critical evidence-based tool to support teacher growth (Kraft, Blazer \& Hogan, 2018). A number of studies have found large positive effects of coaching on teachers' instructional practice and student achievement. However, few studies examine factors and dynamics that define the effect of instructional coaching on teachers' ability to use technology in ways that support student engagement and learning in $\mathrm{K}-12$ settings. So we invested in instructional technology coaches by providing them with training and support including mentors to connect with throughout the year. Digital Promise is conducting research to understand how this program impacts teacher confidence in using technology for teaching and learning and more.
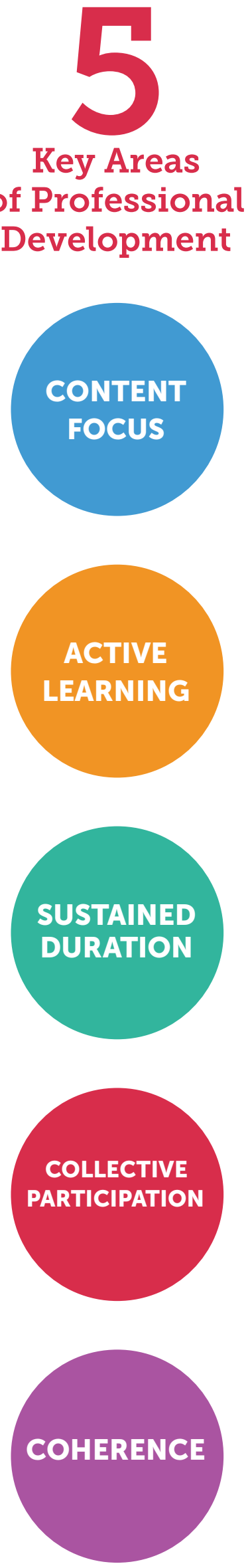

\section{What do we hope to learn from the DLP?}

From a research perspective, we asked, "What are the conditions necessary for instructional coaching to effectively foster powerful use of technology for learning?" In other words, how do we set up coaching to help teachers use technology more powerfully?

Our theory of change is that instructional technology coaching is an effective PD model for driving increased student and teacher success through increased impactful use of technology in the classroom.

It's important to be clear that technology alone is not the end game. Technology in the hands of skilled teachers and engaged students in full support of powerful learning is what matters.

Effective PD addresses five key areas - content focus, active learning, sustained duration, collective participation, and coherence (Desimone \& Pak, 2017).

CONTENT FOCUS: Activities that support teacher learning in teaching specific content areas.

ACTIVE LEARNING: Opportunities that directly engage teachers in designing and/or trying teaching strategies.

SUSTAINED DURATION: Opportunities that provide teachers with sufficient time to learn, practice, implement, and reflect on strategies that improve their practice.

\section{COLLECTIVE PARTICIPATION:}

Opportunities where teachers can share ideas and actively become the advocates of their own learning.

COHERENCE: Activities that are consistent with the school/district goals and curriculum, and teacher/student needs. 
Instructional coaching touches all five areas, and many research efforts have shown that coaching improves the quality of instruction and increases engagement with fellow teachers (Charner \& Medrich, 2017). However, the number of coaching hours needed is not fully defined. Research suggests that a range of 14-50 hours per year is needed for PD to be effective (Wei, Darling-Hammond \& Adamson, 2010; Yoon, Duncan, Lee, Scarloss \& Shapley, 2007).

\section{What is powerful use of technology?}

Drawing on the Framework of 21st Century for Teaching and Learning (Ravitz, 2014), we define "powerful use of technology" as when educators have the ability to engage their students in using technology to:

\section{- SELECT RELEVANT TECHNOLOGY TOOLS:}

Students can select relevant technology tools and resources for learning.

- DEVELOP COLLABORATION SKILLS: Students can work together to solve problems, complete tasks, and accomplish common goals.
- DEVELOP COMMUNICATION SKILLS: Students can thoughtfully cross borders, connect with experts locally and globally, and share what they have learned orally, in writing, and through a variety of media.

\section{- DEVELOP CREATIVITY AND INNOVATION}

SKILLS: Students can generate and refine solutions to complex problems or tasks using ideation, synthesis, and analysis processes in combination with technology.

- DEVELOP CRITICAL THINKING SKILLS: Students can ask and investigate complex problems, evaluate different sources of information, and draw conclusions based on evidence and reasoning.

- DEVELOP AGENCY: Students can take responsibility for their learning by setting and driving towards personal goals, by identifying their own topics, processes, and strategies, and by reviewing and reflecting on their work. 


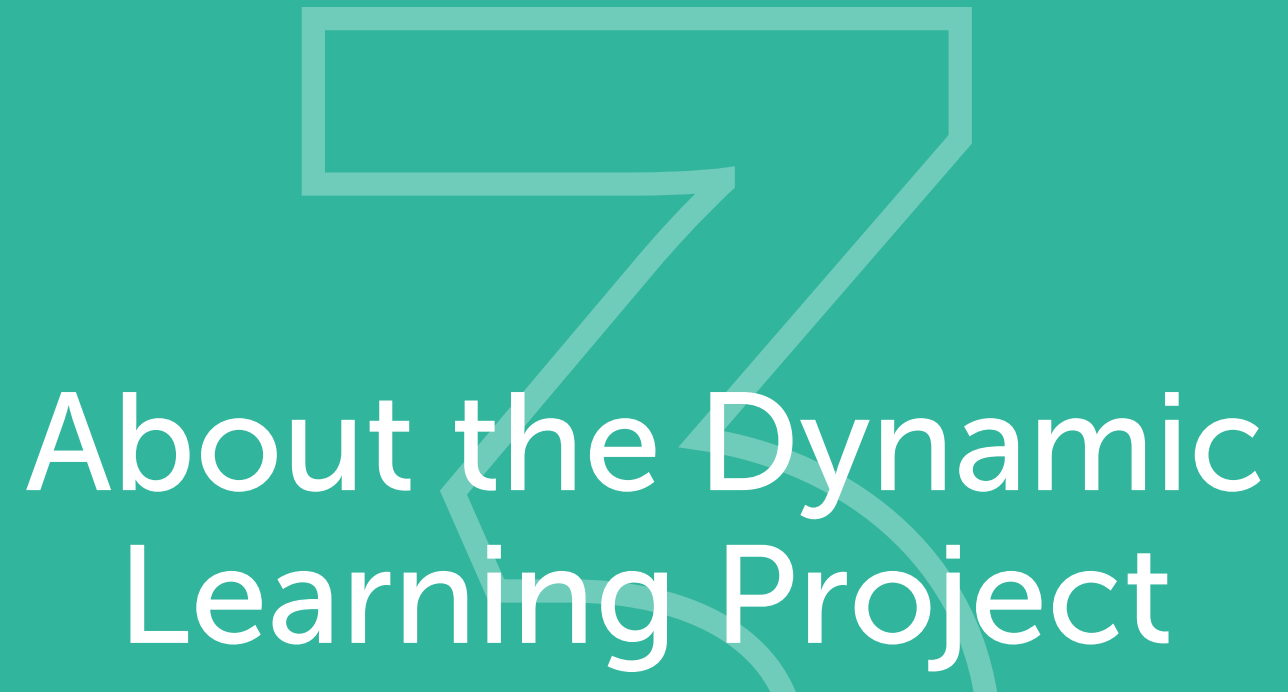




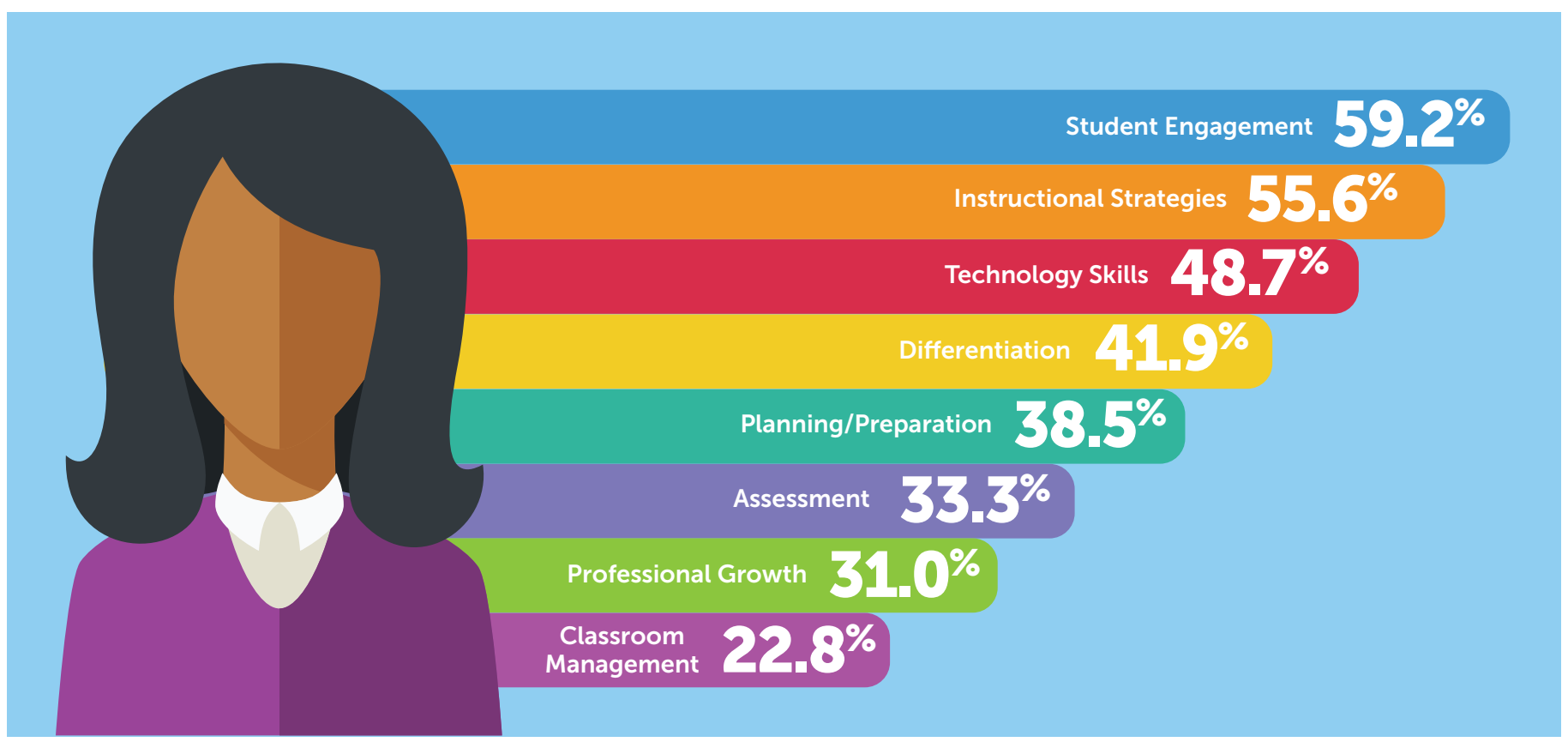

Figure 1. Percentage of DLP teachers who reported working with their coach on each of the focus challenge categories over the course of the year.

\section{ABOUT THE DYNAMIC LEARNING PROJECT}

\section{What is the Dynamic Learning Project coaching model?}

Working with 50 underserved schools in 20 school districts across five regions-Alabama, California, Pennsylvania, South Carolina, and Texas-we provided grants to support one site-based, full-time instructional technology coach for each school for one year. The DLP program team provided a profile of suggested qualifications for DLP coaches to districts, which district leaders and principals could use as a guideline in their hiring processes. All coaches had prior teaching experience, and most had taught within the school where they were hired. In selecting coaches, principals tended to prioritize a strong history of innovative teaching practices and existing relationships with school staff over technological knowledge.

DLP coaches provided individualized support to teachers over the course of four eight-week coaching cycles. During each cycle, coaches worked with teachers individually to help them select, tackle, and then reflect upon a classroom challenge(s). The majority of teachers participated in one cycle; coaches worked with approximately the same number of teachers during each of the four cycles, allowing more than 1,110 teachers (out of a teacher population of 2,250 ) to participate in the DLP in the pilot year.

During each cycle, each teacher collaborated with the coach to identify one or more challenges to focus on, and for each, brainstormed and selected an innovative, technology-based strategy for tackling the challenge(s). Teachers selected focus challenges from the following categories (in order of popularity): student engagement, instructional strategies, technology skills, differentiation, planning/preparation, assessment, professional growth, and classroom management (Figure 1).

The coach then provided classroom support to the teacher throughout the implementation process in the form of modeling, co-teaching, and observations. Finally, the coach and teacher reflected on the experience and discussed next steps. If the teacher felt that enough progress had been made on the initial focus challenge, additional challenges could be tackled within one eight-week cycle.

\section{How are the coaches and principals supported?}

Participating schools received sustained mentoring and ongoing PD, including through participation in 
both DLP-wide and regional PLN. Coach and principal engagement began with a five-day Summer Institute where they met the mentor assigned to support their geographic region. Over the course of the year, mentors served the role of accessible experts who could provide an outside perspective and personalized support to coaches and principals. After an initial school visit in the fall, mentors held virtual, biweekly meetings with coaches and monthly meetings with principals. Participants reconvened at a regionally-based Winter Institute.

\section{What resources were provided to coaches?}

During the first eight weeks of the school year, coaches participated in a book study, followed by one or two live online training sessions per month delivered by mentors. They were provided with a list of challenges that teachers might encounter and associated strategies and tools. Coaches were provided with digital resources to maintain coaching logs of their classroom visits, meetings, and the progress of coached teachers. Technology skill and instructional coaching tips were provided throughout the year to coaches in weekly newsletters ${ }^{1}$.

\section{What is the principal's role in the DLP?}

After classroom teachers, the principal as school leader has the largest impact on student learning (Leithwood, Seashore, Wahlstrom \& Anderson, 2010; Matsumura, Sartoris, Bickel \& Garnier, 2009). Principals must fully buy in for any intervention to succeed, and the DLP is no different. The principal's role was to support coaching in their building by maintaining program fidelity, reassuring teachers concerning the confidentiality and collaborative nature of the coach-teacher relationship, ensuring that the coach did not play an evaluative role, and protecting the time of the coach from other assignments.

Moreover, principals have the ability to make important changes to how the school functions, what the school's goals are, and how the principal and school staff communicate in response to coach feedback.

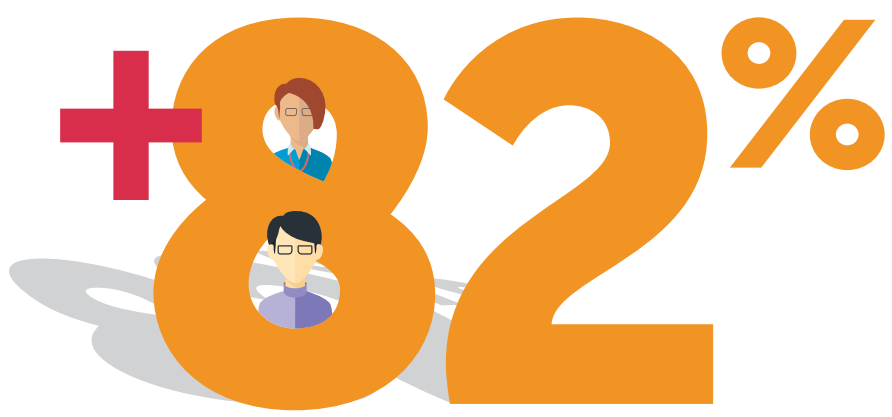

of district leads reported the DLP is aligned or strongly aligned with district goals for PD and/or technology integration.

\section{What is the school district's role in the DLP?}

Each participating district identified one or more leaders to support coaching in participating schools by removing barriers to success, enacting plans for sustainability, and articulating the project to district stakeholders and the greater community. More than 82 percent of district leads reported that the DLP is aligned or strongly aligned with district goals for PD and/or technology integration.

\section{How was data gathered?}

An important part of this project was to design and implement a research project to learn more about the model and also provide data back to the schools to support continuous improvement. To answer the research questions, we collected and analyzed both qualitative and quantitative data. Quantitative data was gathered from all 50 schools, including surveys of participating teachers, coaches, principals, and district leaders. Qualitative data was primarily gathered from four volunteer case study schools. All case study schools serve predominantly low-income students, and each of the four is located in a different geographic region. Using this mixed methods design resulted in a more complete understanding of the program and its impact.

Teachers, coaches, and principals completed two surveys-one at the beginning of the year and one at the end of the year. Nearly all coaches (94 percent) and principals (90 percent) completed both surveys ${ }^{2}$. We surveyed teachers who did and did not participate in the program. The surveys for participating teachers

${ }^{1}$ See appendix 2 for a detailed list of coach resources.

${ }^{2} \mathrm{See}$ appendix 1 for detailed sample sizes. 
asked them to agree or disagree with statements on teacher use of technology, principal-coach-teacher partnership, coach-teacher collaboration, and student engagement and learning. The surveys for the non-participating teachers mainly inquired about their use of technology and student engagement and learning. Finally, we surveyed district leads from the 20 districts to understand the alignment of the DLP with their district goals and the possibility of sustainability and scalability of the DLP in each district. Eighteen (90 percent) of the district leaders responded to the survey.

For each of the case study schools, we made three visits (at the beginning, in the middle, and at the end of the pilot year) to interview principals, coaches, and between three and seven participating teachers. We also visited the classroom of each teacher who was interviewed to observe them teaching on their own (in the first and third visits), and while working with their coach (in the second visit).

Student perspective is also important in evaluating the impact of the DLP. We collected survey data from students of case study teachers following our first and third visits. The surveys asked students to agree or disagree with statements about their use of technology and level of engagement in the classrooms of their DLP teachers. A total of 798 students across the four case study schools completed both surveys.
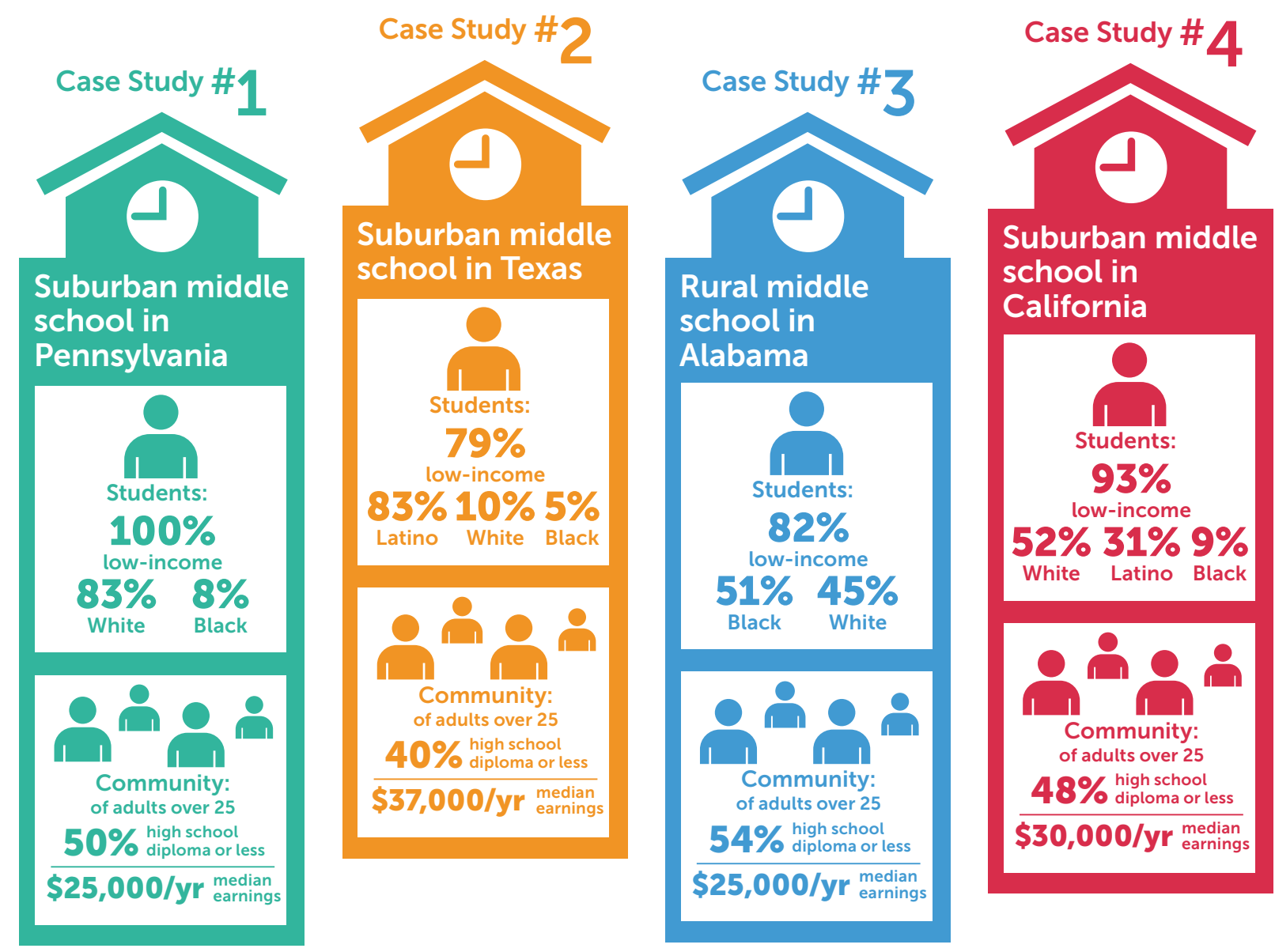


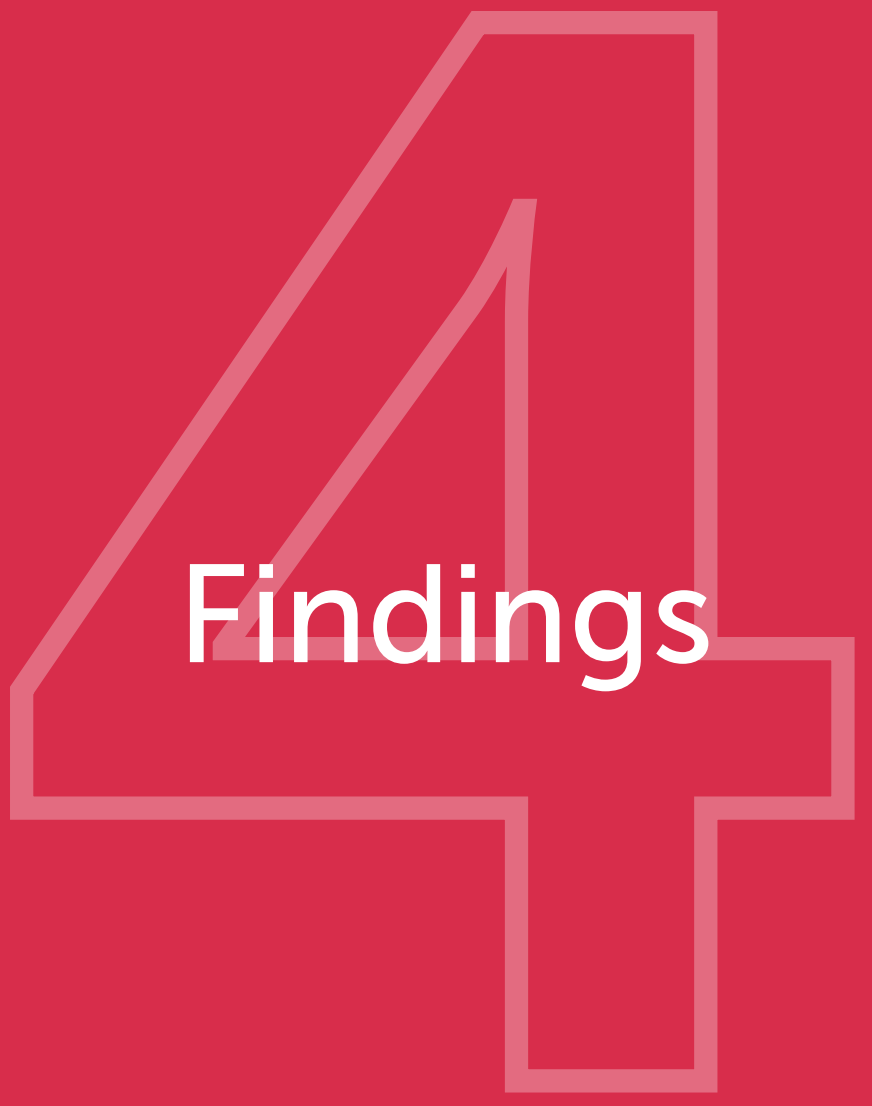




\section{FINDINGS}

Let's go back to our theory of change behind this project-that instructional coaching will drive increased student and teacher success through increased effective use of technology. In this pilot year, we measured student and teacher success on a variety of measures, and found important improvements.

\section{Teaching more powerfully}

Teachers described being "re-centered" and "refocused" as a result of the coaching they received through the DLP. As one teacher explained, "After close to 20 years of teaching (...) having a coach and having the ability to do these different types of activities has re-energized my love for it." At the end of the year, teachers who reported having received more support from their coach also reported greater job satisfaction.

Our data shows that after one year of working with their DLP coach, teachers are using technology more frequently and in more powerful ways. At the end of the year, 86 percent of the DLP teachers stated that their technology use was more frequent this year than previous years. This was the
Teachers That Stated Their Technology Use Was More Frequent This Year Than The Previous Year

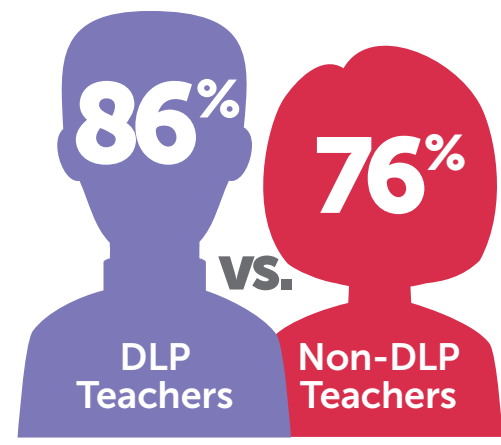

Teachers That Reported They Made Considerable Progress In How They Use Technology

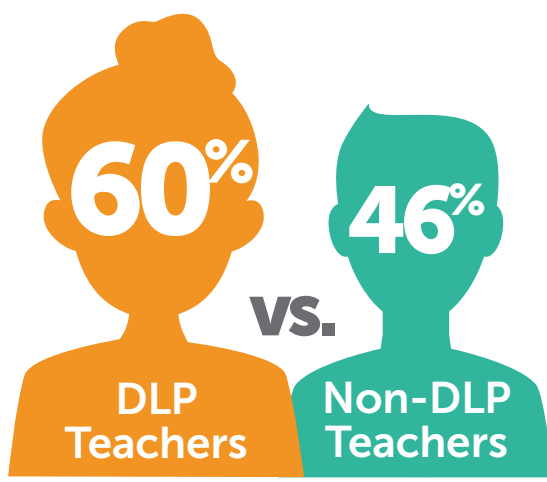

case for 76 percent of teachers who didn't participate in the DLP, suggesting that there are benefits even for non-coached teachers, perhaps as a result of culture shifts, access to the coach, increased peer collaboration and principal support.

While using technology more frequently is a foundational piece of using technology more powerfully, the ways that teachers are using technology - the how, in addition to the how often-is even more important. At the end of the year, 60 percent of the DLP teachers reported that they had made considerable progress in how they use technology in their teaching practice, compared with 46 percent of their colleagues who didn't participate in the DLP.

More than 80 percent of DLP teachers agreed that they have the ability to use technology in powerful ways when it comes to student selection of technological tools, collaboration, creativity, communication, critical thinking, and agency (Figure 2). Half of the teachers involved in the case studies specifically noted that coaching helped them increase their ability to differentiate instruction. Some teachers explained

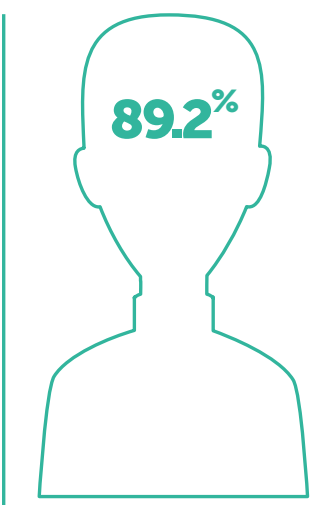

Selection relevant tech tools

DLP Teacher Powerful Use of Technology

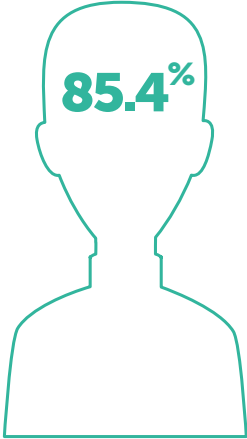

Collaboration

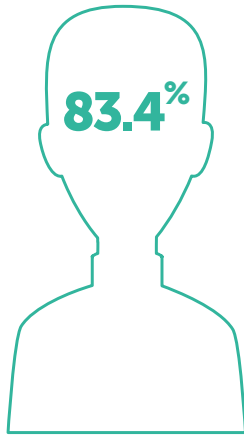

Creativity

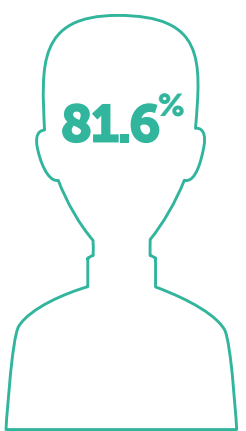

Critical Thinking

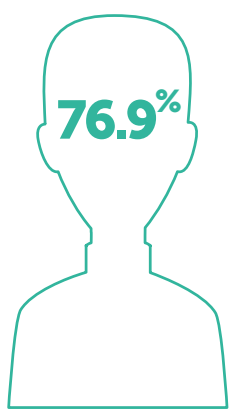

Communications

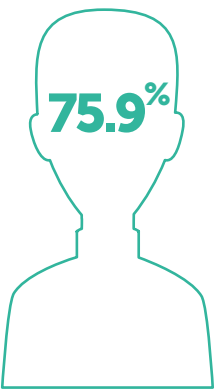

Agency

Figure 2. Percentage of teachers who agreed or strongly agreed that they had the ability to actively engage their students in using technology in powerful ways. 
that often in their classrooms, differentiation would take the form of small, rotating groups. A veteran teacher with more than 20 years of teaching experience elaborated: "I rarely do any kind of whole group instruction anymore [...] the way I deliver things now is in different chunks and it's more geared toward here's the specific things for this group. It's more differentiated than it ever has been. That's definitely different lesson planning than I've done before."

The teachers who were coached (DLP teachers) reported significant increases in using technology for both teaching content and pedagogy-in other words, coaching for educators. As one teacher explained, "[The students] have ownership of what they're doing and what they're learning instead of me just handing them things like, 'Okay. Do this.' They've created things themselves that they can share with each other, and (...) [the students] have gotten better about finding specific things to provide feedback on, instead of just saying, 'This is awesome.'"

Importantly, coaches, principals, and teachers reported that coaching led to this increased student engagement in learning even when it's not the main challenge they focus on. Principals, teachers, and

\section{Teacher Progress in Technology Skills and Use}

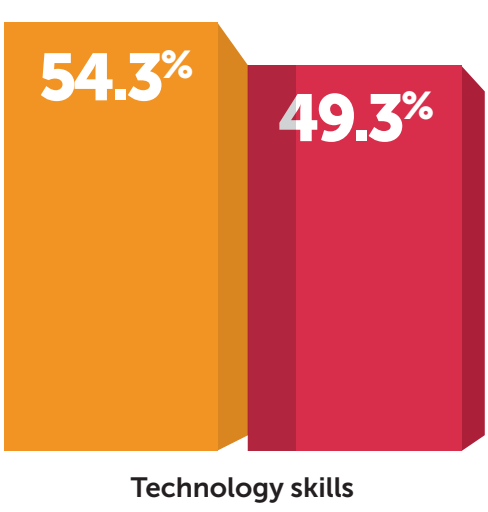

DLP Teachers

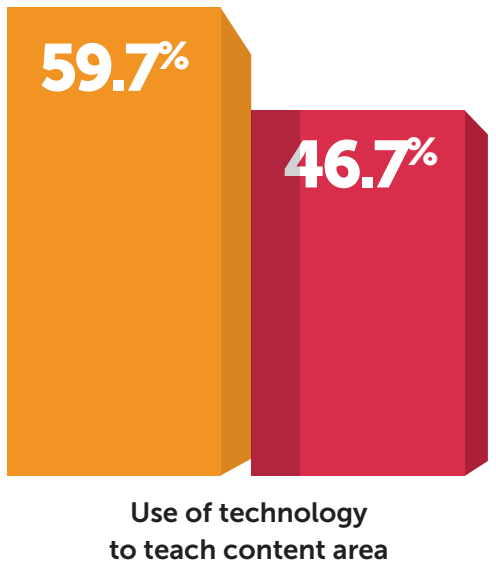

to teach content area

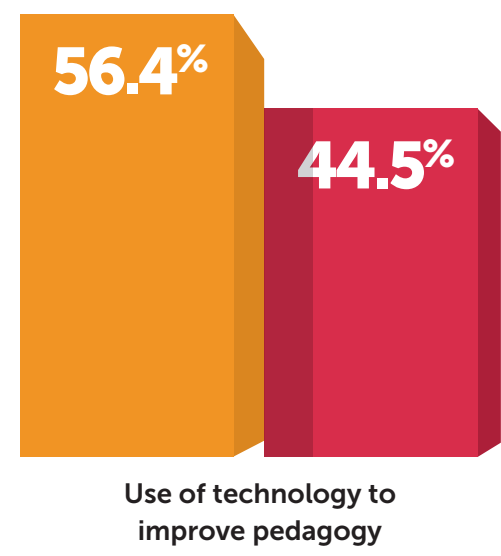

Figure 3. Percentage of DLP versus non-DLP teachers who reported considerable or extreme progress (as opposed to no, slight, or moderate progress) in the development of their technology skills, and selection and use of technology to teach specific content and to improve teaching approaches (pedagogy).

teachers are using technology both to support what they are teaching and how they are teaching it (Figure 3). What is especially interesting is that there was not a significant difference in how DLP and non-DLP teachers perceive their basic technology skills. But there is a statistically significant difference in how DLP teachers believe they now use technology for both content and pedagogy, which is important from the perspective of how to improve teaching.

\section{Student engagement grew as powerful technology use increased}

Students reported using technology more often for working with their peers, solving complex problems, developing communication skills, and keeping track of their own work. In other words, powerful use of technology by students increased after one year of coaches all increasingly believed that DLP coaching improves student learning and engagement; coaches were the most positive about the potential of the DLP with more than 95 percent of coaches believing that the DLP advances student learning and engagement (Figures 4 and 5).

In response to a question asking what the most surprising impact of the DLP had been, a teacher responded that due to increased differentiation she'd made working with her DLP coach, "There's not one kid off task. It's surprising to me that they've all bought in. That's so cool. [Before,] you'd always have four or five kids who are just reluctant or not motivated. But the ones that were the least motivated at the beginning of the year are now doing things, doing it with gusto." 


\section{Coach and Principal Belief that Coaching Can Improve Student Learning and Engagement}

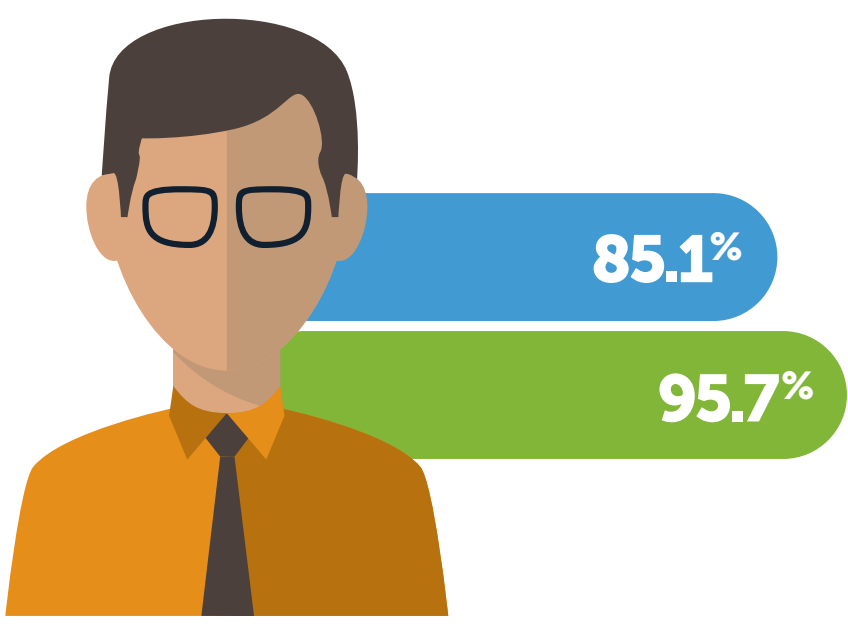

Coaches

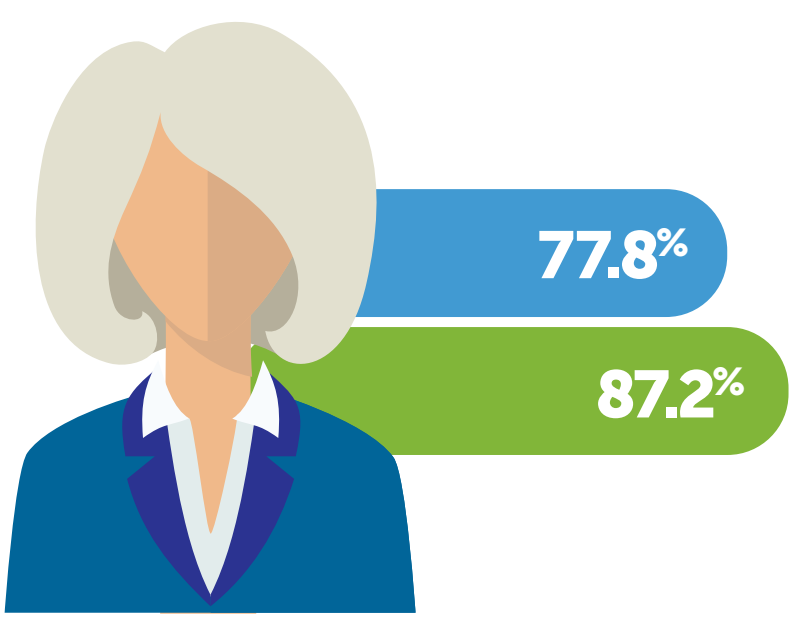

Principals

At the beginning of the year

At the end of the year

Figure 4. Percentage of coaches and principals who agreed or strongly agreed that instructional coaching can improve student learning and engagement.

\section{DLP Teacher Belief that Coaching Can Improve Student Learning and Engagement}

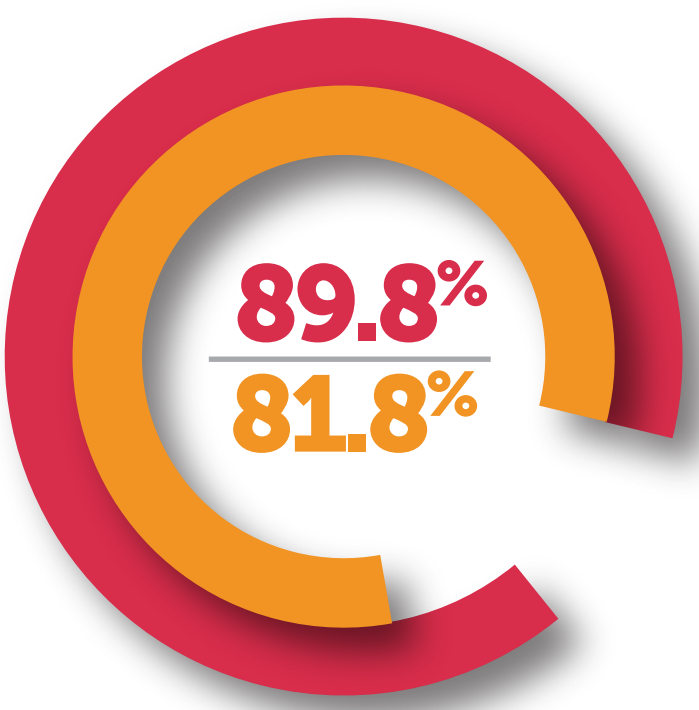

Student Learning

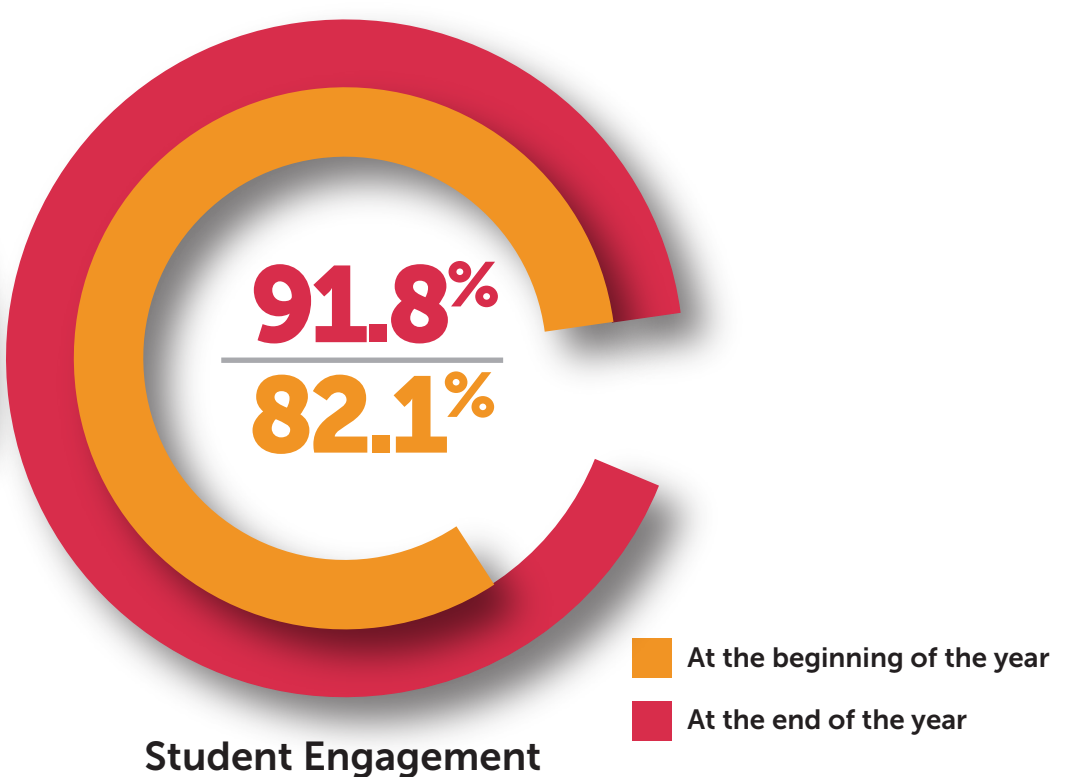

Student Engagement

Figure 5.Percentage of DLP teachers who agreed or strongly agreed that providing educator support through instructional coaching improves student learning and engagement. 


\section{Coaches and principals grew in coaching and leadership skills}

The DLP was not designed to be only about teachers. It is a systemic approach that carefully considers the role of coaches, mentors, and principals in supporting teachers and in shifting school culture.

At the end of the pilot year, coaches were significantly more confident in their own coaching skills and ability; 89 percent of coaches rated their general coaching skills as high or extremely high compared "indispensable" and "an absolute must," especially in the beginning of the year as they were getting the program off the ground, and highlighted the mentors' role in establishing regional PLNs. The PLNs themselves were also instrumental for coaches. As one coach explained, "We meet all the time, we talk all the time. If there's a training, we all sign up to go. We try to do as much together as we can. We visit each other's schools; (...)we talk to each other daily (...)That to me has been almost even more beneficial than anything."

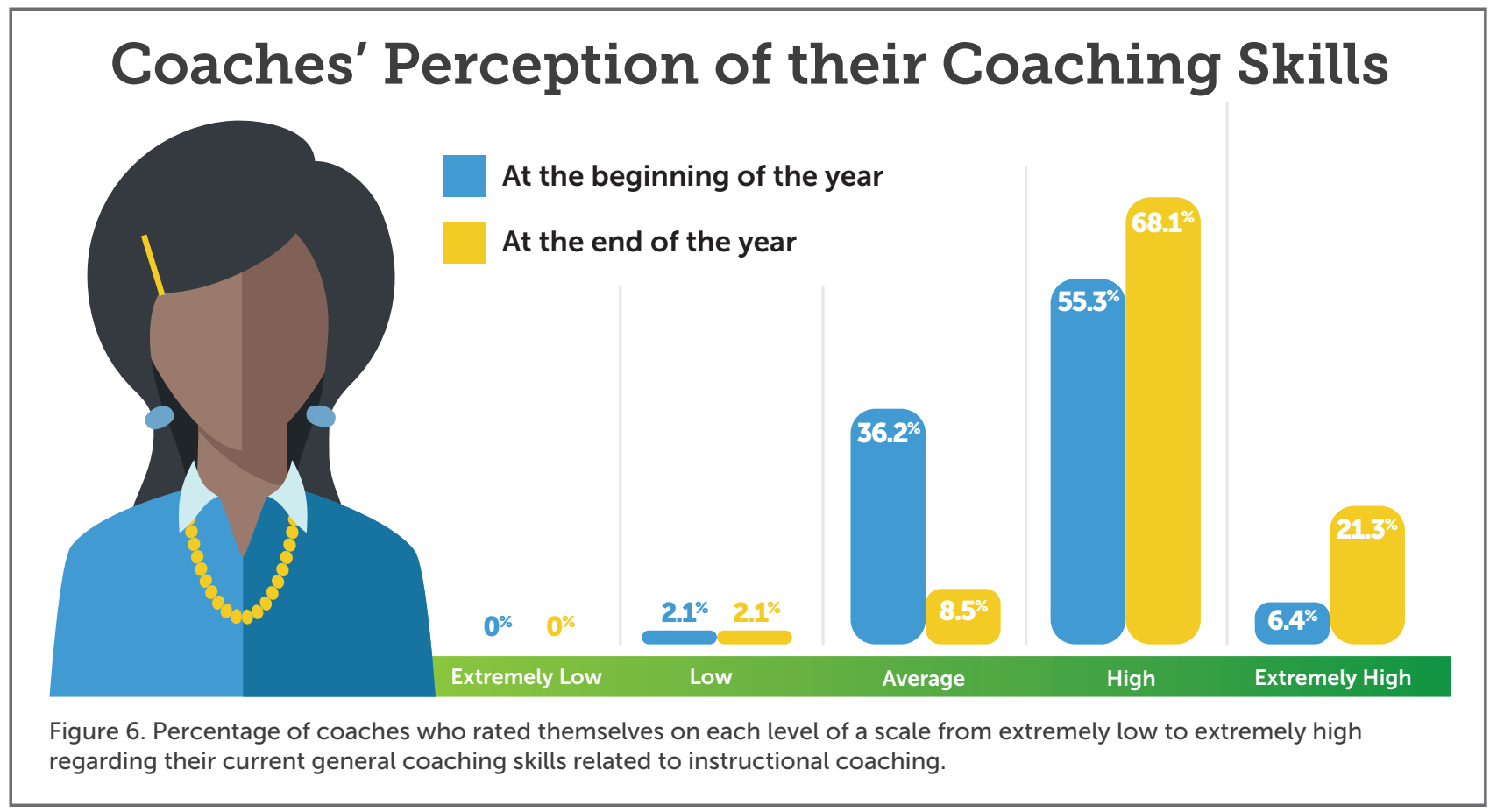

with just 62 percent at the beginning of the year (Figure 6). Coaches attributed their growth to the opportunities for connection, collaboration, and peer learning fostered by the in-person Summer and Winter Institutes, their mentor support, and their regional PLNs. Coaches also mentioned autonomy as a key to success. As one coach shared, "Without autonomy and authority, an instructional coach cannot do their job well. I was given autonomy to get my job done(...) [and] I was also given the authority to make decisions in the best interest of the school and students." Increased autonomy is also a reflection of principals' successfully navigating and supporting the coach as a leader in the school building.

Nearly all coaches and principals agreed that the mentor's role was essential for implementing the program. Coaches described their mentors as
Some of the largest meaningful gains were found in principal skills. In the fall, only 60 percent of principals reported high or extremely high levels of confidence in their leadership skills related to instructional coaching. By the end of the pilot year, 95 percent of principals reported high or extremely high levels of confidence in their leadership skills related to instructional coaching (Figure 7). In discussing their growth, principals shared that they especially valued the face-to-face training at Summer Institute and Winter Institute and the opportunity to learn from one another. Moreover, the percent of principals who strongly agreed with the power of instructional coaching to improve student engagement and learning increased by almost 10 percentage points. In other words, not only did principals grow in their own leadership skills when it comes to supporting coaches and teachers, but principals are even more committed 


\section{Case Study \#1: Improving Classroom Management Suburban Middle School in Pennsylvania}

Although the goal is more powerful use of technology to support important skill development, managing a class so that learning can happen is a skill a non-evaluative coach can support.

Through coaching, a science teacher working in a high-poverty, highly diverse middle school transformed her pedagogical philosophy and instructional design. In September, as reported by researchers, students interrupted instruction with frequent misbehavior, resulting in a visibly frustrated teacher. By January, though, the coach and teacher had worked to develop a more productive environment where

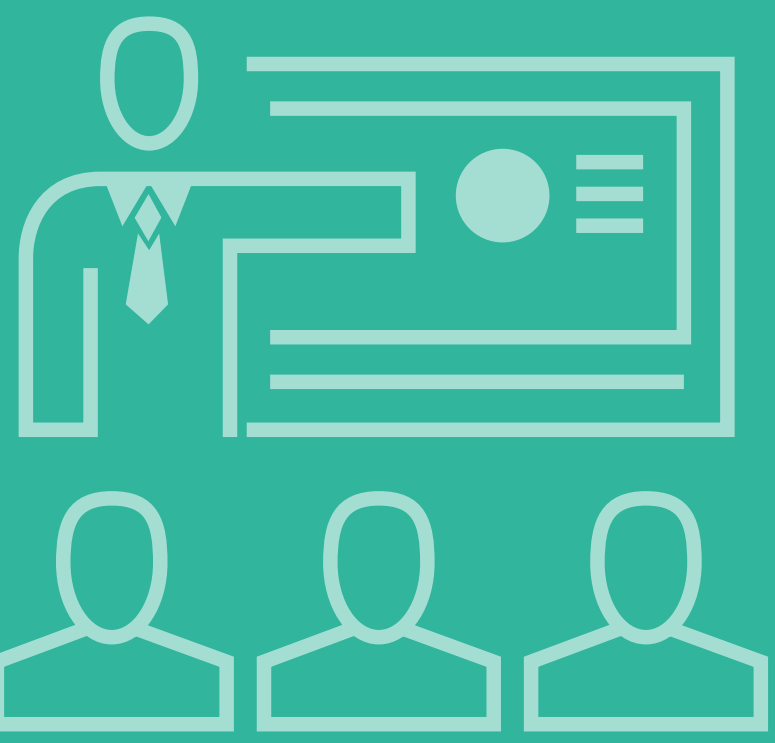
students worked independently on learning activities in Chromebooks while the teacher pulled students aside one by one to provide individualized support.

During this classroom visit in January, the teacher was observed using encouraging language and was clearly developing a more positive, community-oriented environment in her classroom. Yet, although students were behaviorally engaged, they were not provided opportunities to think critically, collaborate, or be creative.

In May, it was hard for researchers to believe they were visiting the same classroom. Students entered with a smile on their faces and shared inside jokes with the teacher. They immediately sat down and began the warm-up activity in which students chose to either play a game on a learning app to review parts of a cell, read science books, or enrich their knowledge of cells using other learning software. The teacher then played a video for the whole class describing bacteria. Students laughed (appropriately) at how "gross" bacteria are, and were completely engaged throughout the video while taking notes on their Chromebooks. The teacher elicited voluntary responses by students eager to share what they'd learned.

The teacher then asked students to put their heads down and close their eyes in order to anonymously vote whether they wanted to move forward by partnering with classmates who had not yet passed the previous quiz or making those students stay back. Every student in the class voted to help their peers move forward. The teacher maintained anonymity so that no student knew whether their partner had or had not passed the quiz.

Then, in pairs, students completed a pre-lab where they observed "little protozoa moving around" to prepare for what they would see in the microscope in the following class. Students were visibly excited about the lab. Through weekly or bi-monthly in-person meetings, the coach and teacher worked together to develop strategies that foster student engagement and learning, and provide opportunities for collaboration, critical thinking, and student voice. 
to the potential of instructional technology coaching to achieve school goals for student success.

One teacher summarized the value of principal support: "I think more than anything, [our principal] celebrates when people use new things in their classrooms. So when she comes to observe (...) she sees what you're doing and then she does newsletters that directly celebrate what people are doing in their classrooms. I think that makes you feel like, 'Oh, then I want to try some new things.' (...)It's a really friendly growth environment."
As the first year of the DLP progressed, more DLP teachers agreed that teachers in their school are encouraged to take risks. By the end of the pilot year, 87 percent of participating teachers reported that risk-taking is encouraged in their school. Not only that, but compared to non-DLP teachers, participating teachers were significantly more likely to believe that risk-taking is encouraged in their school.

There is an essential distinction, however, between asking teachers if they are encouraged to take risks, and then asking coaches whether those risks were ac-

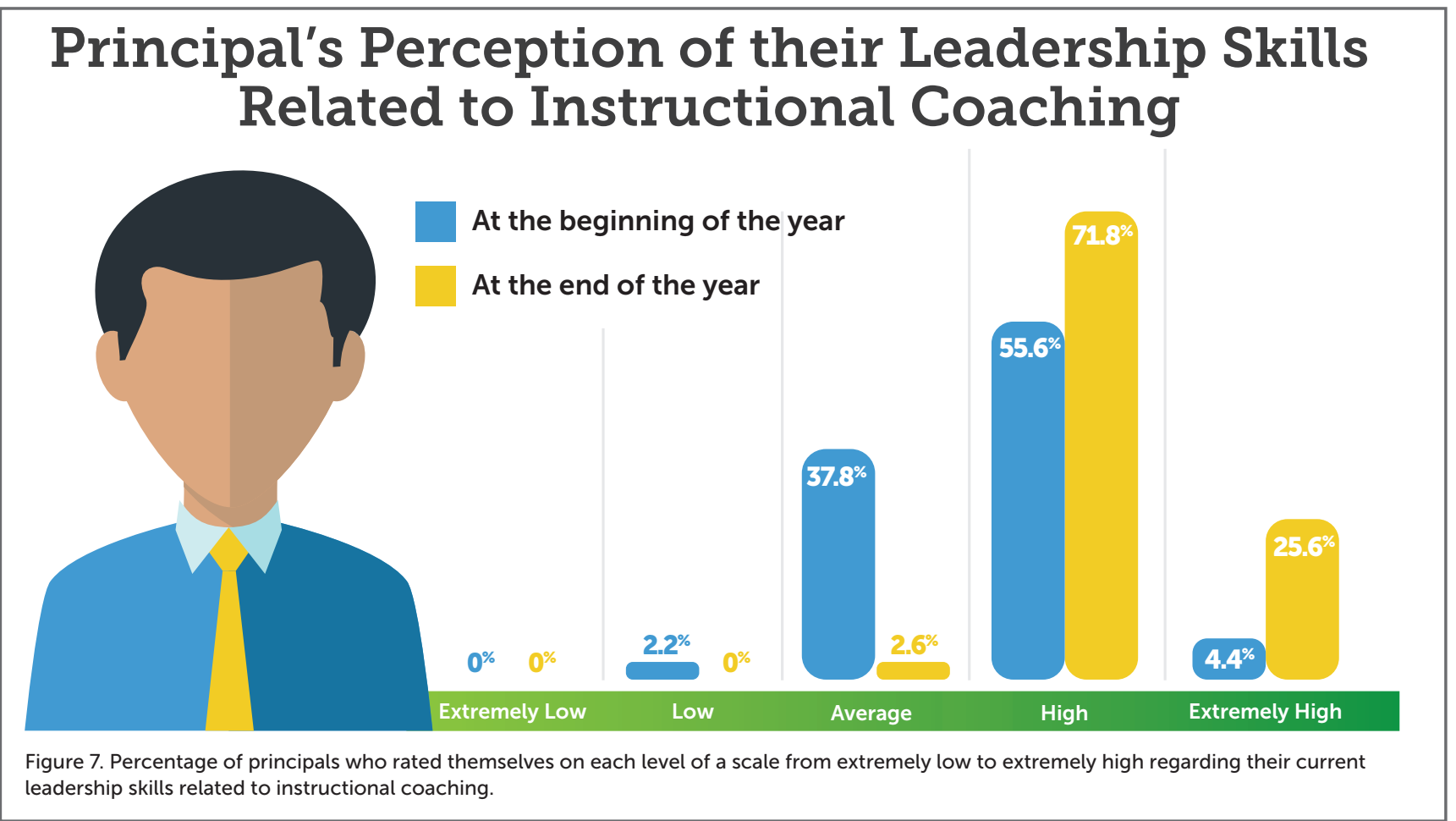

\section{How is the DLP changing school culture?}

Increased risk-taking, collaboration, and a general boost in being open to change are promising indicators that instructional technology coaching is a game-changer for schools, and particularly for under-resourced, low-achieving schools. The DLP gives teachers support and encouragement to try new things in their classrooms and take risks. Learning something new involves risk and a possibility of making mistakes-feeling safe enough to try something new, despite the possibility of making mistakes, is a necessary ingredient for learning. And if we want students to be innovative risk-takers, we need their teachers to be just as inventive and risk-taking. tually taken. At the end of the pilot year, coaches felt less confident that the teachers they coached were taking risks, with 54 percent of coaches reporting that teachers are very or extremely willing to take risks. In the coming years, we will want to see the number of coaches reporting that teachers take risks to increase; still, the perception of teachers that risk-taking is increasingly encouraged remains a strong signal that a culture shift is underway.

Risk-taking must also be modeled at the very top if it is to become part of the culture. Principals described the DLP as encouraging them to model risk-taking, experimentation, and continuous learning. As one principal said, "One of the things that we've 
communicated to staff regarding our focus that we developed and brought back [from the Summer Institute] is that we want people to be risk-takers, and to fail forward, and we've reassured them that there's not a gotcha. Please don't give up if something's challenging or doesn't work the first time. But to change the mindset and culture of a campus that hasn't experienced the absence of the gotcha for not being compliant or following whatever directive has been presented takes some time, so [my coach] and I are working really hard to be careful about building those trusting relationships and a risk-taking culture. So, I think we're persistent and...[our coach] has seen some people be more open who weren't before."

We saw increases in collaboration among DLP teachers, as well as growth in collaboration between
DLP and non-DLP teachers. Once teachers learned something with their coach, they were eager to share their new knowledge and skills with their peers. In this way, the coach's reach extends beyond the group of teachers they work with directly, and DLP teachers are also developing their own leadership skills. One teacher explained, "(...)Whatever [our DLP coach] suggests, I then take to [other teachers in my department] and I'm like, 'Look, she suggested this. We should try it.' And then they try it too."

Coaches also provided supplemental support on their campus to all teachers in the form of staff PD, open office hours, newsletters, and individualized support and advice to non-coached teachers. This supplemental support helped set the conditions to shift school culture toward being more collaborative.

\section{Case Study \#2: Trust Leads to Innovation}

\section{Suburban Middle School in Texas}

In Case Study School 2, the administration focused on "building trusting relationships at the site with respect to taking risks" so that the staff knows that they won't be penalized if they try something new and it fails initially. As the principal describes it, the school environment has become more "Google-like." Teachers are beginning to become more open to taking risks and they are supporting one another.

Previously, the school had a reputation of having a "contentious, divided" staff, and now teachers are working together. DLP teachers are promoting coaching to their colleagues by inviting them to visit their classrooms when they are implementing technology, and by suggesting that their colleagues speak to the coach about challenges they are facing. Teachers are choosing as a group to attend technology-oriented, school-wide PD run by teacher leaders within the school, such as a January session on digital badging.

Even teams that have been reluctant to use technology are beginning to embrace change.
The coach explains, "Our eighth grade team is our most reluctant team and two members [who attended the PD on digital badging] took it back to their team at the end of the day and they've now implemented digital badges for vocabulary, which is a campus-wide focus. Now the entire eighth grade is doing vocabulary in their home room with digital badges, from a 25-minute presentation."

\section{This grade-wide approach to collaboration is not limited to eighth grade. For instance, after one teacher working with the coach had initial success using an escape} room activity where groups of students employed skills of critical thinking and creativity to "breakout," the entire seventh grade team approached the coach to ask for help in creating an interdisciplinary grade-level activity following the same model. After they successfully implemented it, the idea spread and sixth grade teachers started to adopt it as well. At the end of the year, the principal, coach, and DLP teachers were hopeful the continuation of coaching will lead to a more cohesive and collaborative campus. 


\section{What did we learn about structuring a successful coaching program?}

The DLP was designed based on important characteristics of instructional coaching identified in the literature review combined with prior experience of the program team. Now, from the data gathered throughout the pilot year, we identified six core attributes of an effective coaching program:

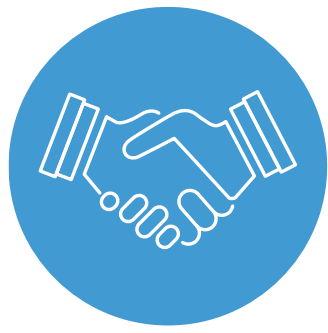

\section{It's a partnership.}

Over the year, 100 percent of the principals and coaches agreed that coaching is a partnership. Teachers also increasingly reported that instructional coaching was a partnership in

their school. Teachers described joint decision-making in their collaboration with their coach and viewed their coach as a thought partner with whom they collectively found creative solutions to teaching challenges. According to mentors and coaches, good coaches scaffold ownership based on teachers' needs and pull back their role as the teacher is ready to take more ownership. Coaches and teachers noted that though they are collective owners of the change process, the teacher drives the partnership and makes the final decisions.

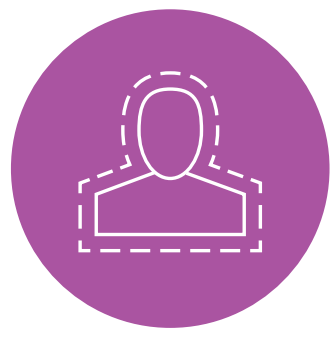

\section{It's personalized.}

Just as students are better supported when learning is personalized, PD programs are also better when personalized. Teachers prefer coaching to traditional PD because coaching is relevant to the specific context of each teacher's background, their classroom, goals, and particular needs of the student population. Coaches tailor their pacing, approach, suggestions, and type of classroom support to meet each individual teacher's unique needs.

"If you do a one-sized model for all the teachers, that's not going to necessarily address their strengths or weaknesses as a teacher. The one-on-one aspect is, I think, the most important part, that you can address each teacher individually based on their strengths and their areas of growth." -Teacher

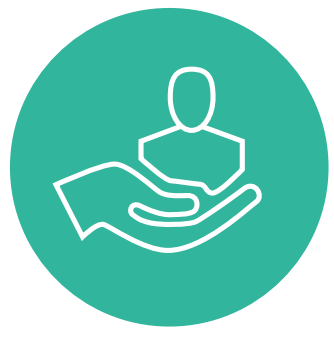

It's non-evaluative.

Over the year, the majority of teachers believed their coach communicated with them in non-evaluative ways. Teachers reported feeling safe to confide in their coach and receive honest feedback and support without fear that the confidentiality of the coach-teacher relationship would be broken. When teachers trusted that the collaboration was non-evaluative, they worked with their coach in an open and transparent manner. This non-evaluative support provided a framework within which teachers felt free to experiment, take risks, and try new things. Teachers who reported non-evaluative coaching were more likely to report progress in using technology in powerful ways in their content area and teaching approaches.

"When she would be in my room working with me, I always felt so comfortable. I never felt judged... because sometimes it is hard to have another teacher in your room while you're teaching, but she never made me feel like that. She was always just extra help that made me feel more confident." - DLP Teacher

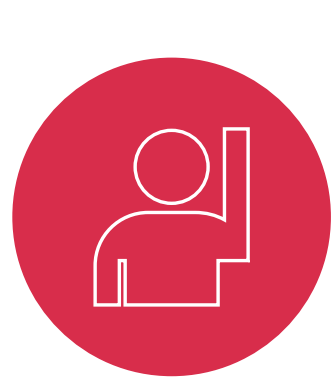

It's voluntary.

When teachers choose to participate in coaching voluntarily, they are more likely to be invested in the process. Indeed, teachers who participated in the DLP used technology more frequently, reported spending more time and receiving a higher degree of support from their coach, and were more likely to believe that their coach worked with them in a non-evaluative manner.

"It's not compliance based, it's real and so people are more likely to engage." -DLP Principal 


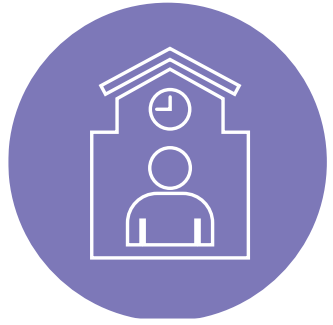

\section{It's situated within the school and classroom.}

Teachers value having the coach situated within the school to support them in their classrooms when they try something new. They appreciate the relevant insights and perspectives that the coach can provide. Additionally, the ability to provide spontaneous and informal support throughout the school day allows for more organic collaboration.

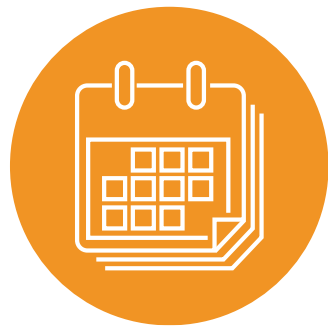

\section{It's sustained.}

The sustained, consistent support over the course of one or more cycles allows time for relationship building, experimentation, and the opportunity to tackle multiple challenges.

Seventy-seven percent of participating DLP teachers received at least 30 minutes of one-on-one coaching per week, with 43 percent of them receiving more than an hour of coaching each week. In the DLP pilot year, teachers received, on average, at least 19 hours of coaching support over the course of the school year. This represents a wide range of total coaching hours; some teachers received 0-8 hours for the year and some received 96 hours or more. Coaches noted that the intensity of support they provide varies based on teacher need. In general, teachers who participated in more than one cycle received more hours of coaching. Additionally, teachers whose coaching was sustained for more than one cycle used technology in more powerful ways, and felt more confident in their abilities to use technology for content and pedagogy.

"I think the beauty of the program is it can be at the teacher's pace. It's not a competition. If it takes us three weeks to get there, great, it takes us three weeks to get there. If we get there in two minutes, then we get there in two minutes." - DLP Coach

When examining instructional coaching through the lens of the five core elements of effective PD-content focus, active learning, sustained duration, collective participation, and coherence-our data presents the DLP coaching program as a powerful tool for improving teacher knowledge, skills, and practice. Because
"[My coach] said, 'Hey, if you have a

question just shoot me a text if you

need me.' So, I'll have my phone in

the drawer, I open it up, just text her,

'Hey, I'm struggling with this,' she'll

come down right away."

-DLP Teacher

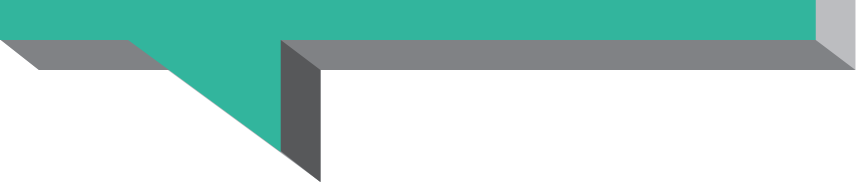

coaching is a partnership that is situated in the school and classroom, teachers frequently have multiple points of interaction with their coach and get regular feedback. Additionally, teachers actively engage in their learning by collaboratively identifying challenges and setting goals that are directly related to the needs of their classroom and the specific content they teach, and they implement new strategies with their coach.

\section{What did we learn about what makes a successful coach?}

In addition to gaining a better understanding of the attributes that contribute to a successful coaching program, we identified several qualities of an effective coach:

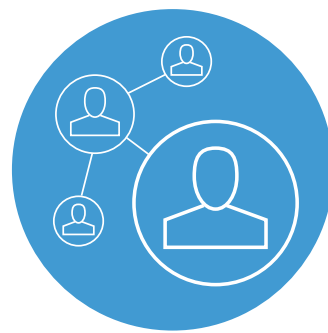

Relationship builder - Teachers, coaches, and principals noted that a successful coach needs to establish relationships with teachers (and students) that are built on trust and respect.

"A good coach is(...)innovative not only in her instructional strategies and what she can find and bring to teachers, but in the way she approaches teachers or staff members and builds relationships and finds the way in, even when the door might not be open."- DLP Principal 


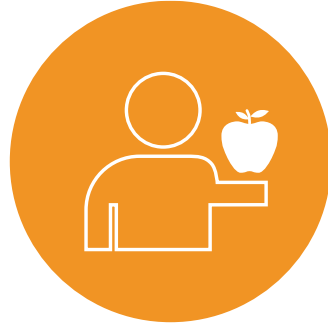

Insider - Teachers, coaches, and principals all agreed that the ideal instructional coach should be a former teacher with previous experience within the school. Since teachers already have an established relationship and trust with an "insider coach," the coach understands the specific and unique needs of the student population, and the students themselves already know and are comfortable working with the coach.

"She knows the kids, she knows the school, she knows the culture. She knows the principal very well(...)she's not an outside observer." - DLP

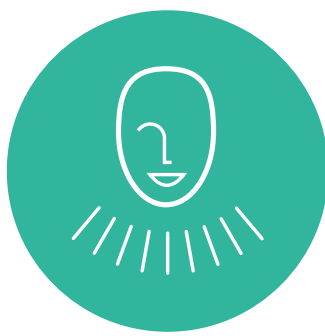
Teacher

\section{Strong communicator -}

Teachers valued an easy, dynamic, and open channel of communication with their coach. They described the ideal coach as relatable, approachable, flexible, accessible, and supportive. Reflecting upon the year, the majority of DLP teachers reported feeling comfortable initiating and having conversations with their coach.

"A good coach listens really well and really tries to get to the root of a problem."- DLP Teacher

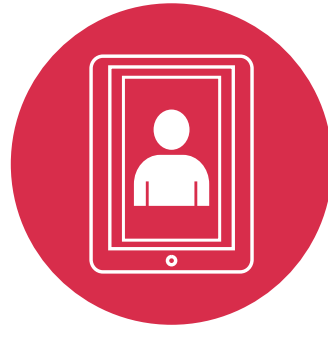

Tech believer - While it is not necessary for coaches to already be tech savvy, they should believe in the potential impact that powerful use of technology can have in instruction. They should also have a growth mindset around technology integration.

"I don't think they have to be (...) the number one techy person in the school, but I think they should be someone who's curious and interested in technology and using technology for learning. So, I think it's their mindset. " - DLP Mentor

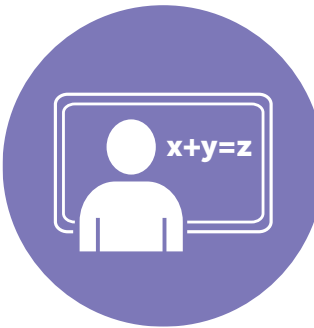

Experienced teacher - Recent teaching experience allows coaches to establish trust and credibility with teachers. It helps them to be respected by their peers and establish the norms of collegiality for collective ownership of the change process. Coaches with backgrounds as classroom teachers can also better empathize with teachers' job-related stresses and constraints.

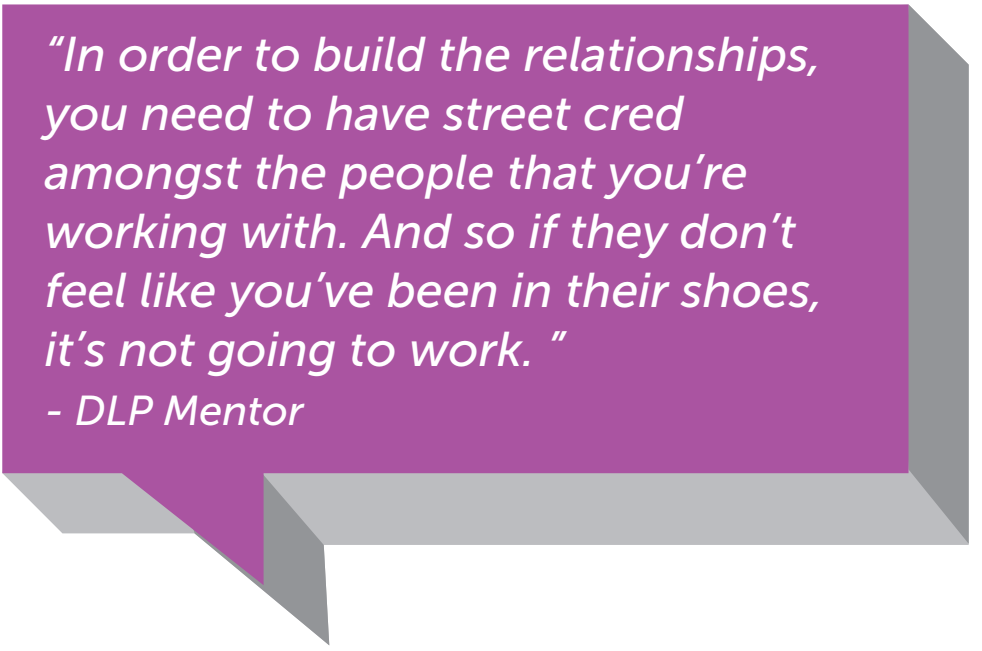




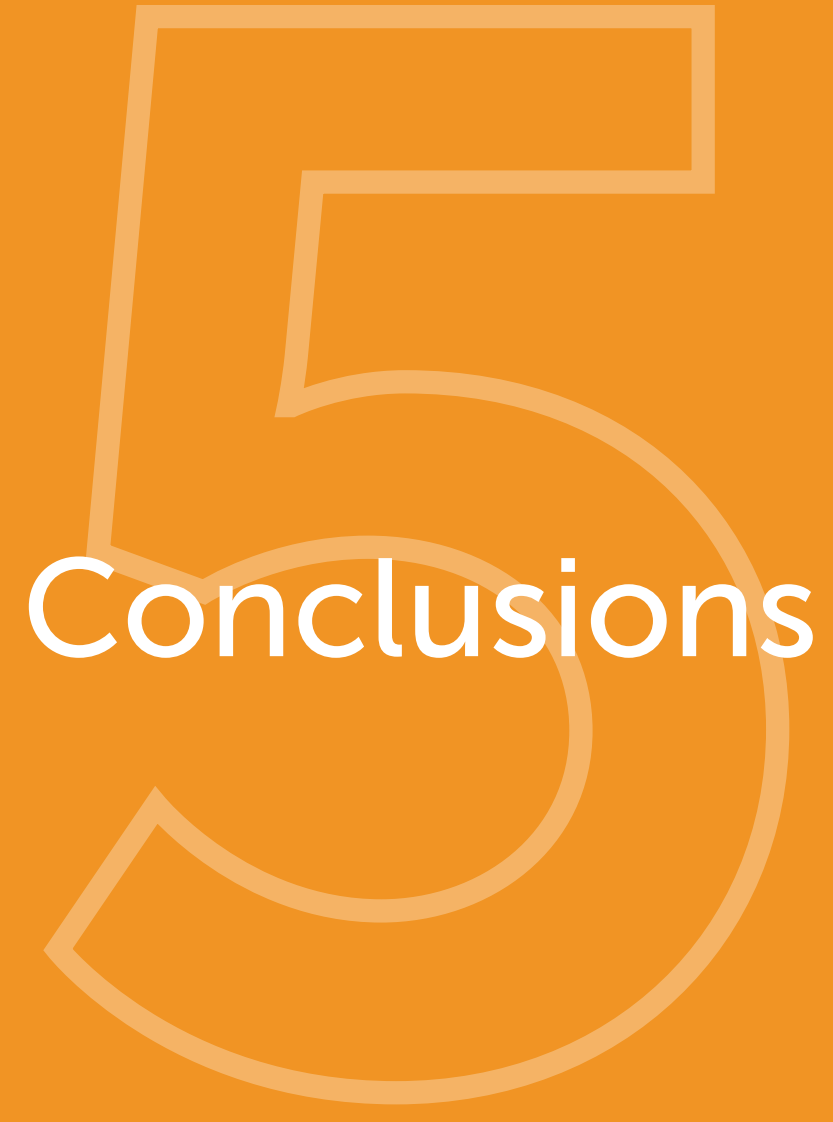




\section{CONCLUSIONS}

The Dynamic Learning Project was launched to help teachers use technology in more powerful ways, because closing the digital use divide is an essential step in improving and achieving equitable educational outcomes, particularly for underserved and under-resourced schools. It was carefully designed based on what research told us about effective coaching, as well as the experiences of the program team.

When the DLP was introduced in the 50 pilot schools, teachers were overwhelmingly positive about the idea of the program and were excited to participate. What is particularly compelling is that at the end of the pilot year, that level of positivity and excitement remained very high.

Moreover, more than half of nonDLP teachers said they would have liked to participate in the DLP.

In year two of the DLP program, districts must procure their own funding for the coach position; Digital

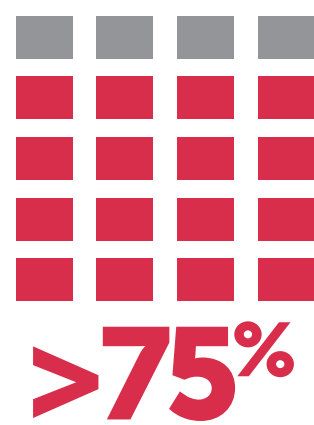

districts

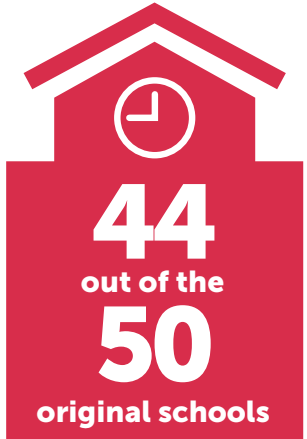

will continue their participation in DLP more progress in their ability to use technology to teach specific content and to improve their teaching approaches. However, particularly in larger schools, when individual teachers participate in multiple cycles, it can limit the total number of teachers who can receive coaching in a year. Some teachers may need multiple cycles to improve their practice to a place where they can continue implementing new approaches on their own, while for others, a single eight-week cycle may suffice to elevate their teaching practice. This question of breadth versus depth is important to consider as we contemplate how the DLP can spur real changes in school climate and teacher behavior; exactly how we define breadth and depth may change depending on school characteristics, teacher aptitude, and more.
Promise will continue to provide in-person and virtual training, as well as mentor support to participating coaches and principals. We know that school districts are operating in a resource-strapped environment, and decisions to fund relatively new positions are made carefully. Sixteen out of 20 districts, and 44 out of the 50 original schools (88 percent), have found a way to continue their participation in the DLP. Five of the districts are greatly expanding the program to include 42 new schools. The choice to continue and even expand the program suggests that school district leaders, principals, and teachers see genuine results and positive impact after the pilot year.

One question we must address in the second year is the relative importance of how much time the coach spends with each individual teacher versus the number of teachers coached. In this pilot year, teachers who participated in multiple cycles reported will help close the digital use divide, and ultimately increase student achievement. Although measuring improvement in student achievement and attributing it to a coaching intervention is complicated from a research perspective, we will expand data collection and analysis and study the feasibility in year two. As we move into the second year, and collect more and new data on the impacts of instructional technology coaching, we look to the DLP teachers to keep us motivated; as one of the teachers noted:

"Too often in education, new programs or practices are introduced, and then are either not followed through, or are forgotten by the following school year. This has been a wildly rewarding opportunity and I hope we are able to continue it in the future." 


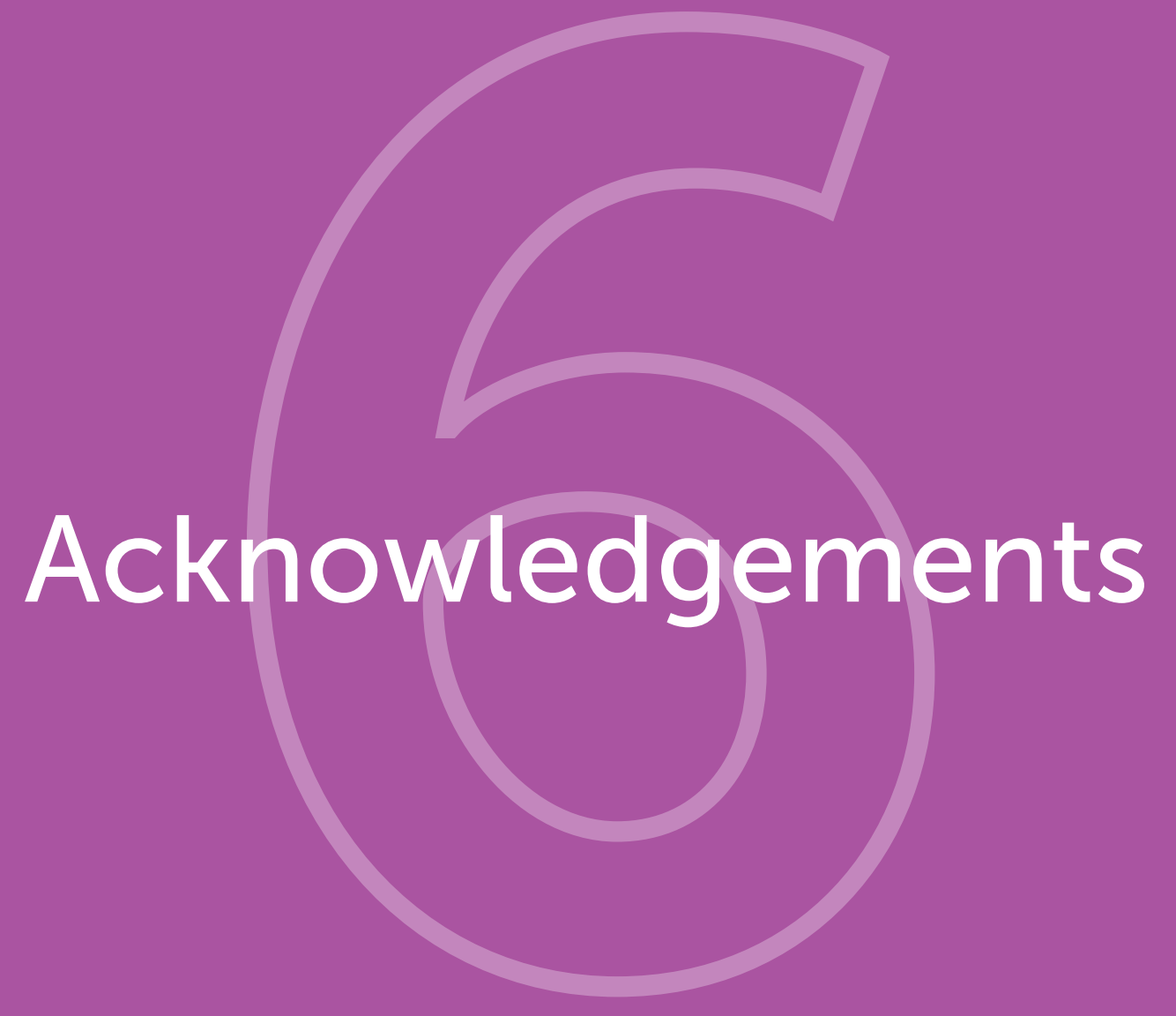




\section{ACKNOWLEDGEMENTS}

Digital Promise is leading the Dynamic Learning Project and conducting research on effective coaching and leadership practices. This project would not be possible without the generous support of Google. Google has provided a grant and countless volunteer hours. Digital Promise has engaged EdTechTeam to provide expert professional development and mentoring to the participating coaches and principals. The authors would like to thank all participating schools, and particularly the four case study schools for completing surveys, and allowing us to visit their classrooms and interview their staff for this project. We would also like to thank Christina Luke and Lisa Jobson for their help with data analysis.

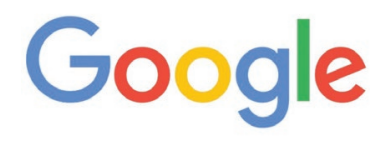




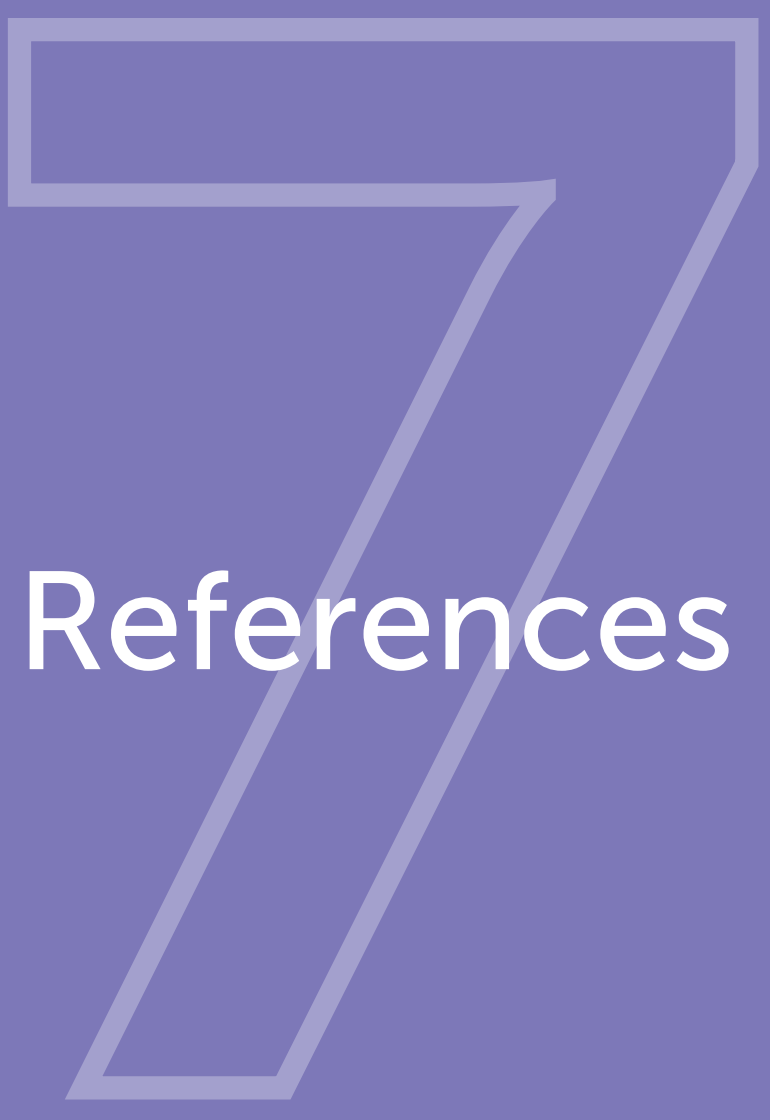




\section{REFERENCES}

Charner, I., \& Medrich, E. (2017). Educator-Centered Instructional Coaching: What the Research Says. FHI 360.

Darling-Hammond, L. (2000). Teacher quality and student achievement. Education policy analysis archives, 8, 1.

Darling-Hammond, L., Zielezinski, M., \& Goldman, S. (2014). Using technology to support at-risk students' learning. Stanford Center for Opportunity Policy in Education. Online https://edpolicy. stanford.edu/publications/ pubs/1241.

Desimone, L. M., \& Pak, K. (2017). Instructional coaching as high-quality professional development. Theory Into Practice, 56(1), 3-12.

Ehsanipour, T. \& Zaccarelli, F. G. (2017). Exploring Coaching for Powerful Technology Use in Education. Center to Support Excellence in Teaching, Stanford University. Online https://digitalpromise.org/wp-content/uploads/2017/07/Dynamic-Learning-Project-Paper-Final.pdf

Education Superhighway (2016). The Connectivity Gap. Retrieved July 20, 2018, from https://www.educationsuperhighway.org/challenge/

Harris, D. N., \& Sass, T. R. (2011). Teacher training, teacher quality and student achievement. Journal of public economics, 95(7-8), 798-812.

Kraft, M. A., Blazar, D., \& Hogan, D. (2018). The effect of teacher coaching on instruction and achievement: A meta-analysis of the causal evidence. Review of Educational Research, 0034654318759268.

Leithwood, K., Seashore, L., Wahlstrom, K., \& Anderson, S. (2010). Investigating the links to improved student learning. Center for Applied Research and Educational Improvement/University of Minnesota and Ontario Institute for Studies in Education at The University of Toronto, 42, 1-333.

Matsumura, L. C., Sartoris, M., Bickel, D. D., \& Garnier, H. E. (2009). Leadership for literacy coaching: The principal's role in launching a new coaching program. Educational Administration Quarterly, 45(5), 655-693.

Ravitz, J. (2014). A survey for measuring 21st century teaching and learning: West Virginia 21st Century Teaching and Learning Survey [WVDE-CIS-28]. DOI 10.13140/RG.2.1.2246.6647 Retrieved from tinyurl. com/21cs-survey-meas.

Reich, J., \& Ito, M. (2017). From good intentions to real outcomes: Equity by design in learning technologies. Irvine, CA: Digital Media and Learning Research Hub.

US Department of Education. (2017). Reimagining the role of technology in education: 2017 National Education Technology Plan update.

Wei, R. C., Darling-Hammond, L., \& Adamson, F. (2010). Professional development in the United States: Trends and challenges (Vol. 28). Dallas, TX: National Staff Development Council.

Yoon, K. S., Duncan, T., Lee, S. W. Y., Scarloss, B., \& Shapley, K. L. (2007). Reviewing the Evidence on How Teacher Professional Development Affects Student Achievement. Issues \& Answers. REL 2007-No. 033. Regional Educational Laboratory Southwest (NJ1). 


\section{Methodological and Analysis Details}

To investigate our research questions, we used a mixed methods design, in which qualitative and quantitative data was collected throughout the year and analyzed separately, and then results were compared and interpreted.

\section{Data Collection}

\section{Quantitative Data Collection}

The quantitative data collection included a one-group pretest-posttest design consisting of one pre-survey (at the beginning of the year) and one post-survey (at the end of the year). These surveys were administered to different groups of participants across all 50 participating schools-principals, coaches, teachers, students, and district leads-as well as non-participant teachers. Most of the survey questions were Likert scales providing five response options. Surveys also included some open-ended questions allowing participants to provide more in-depth answers.

In addition to demographic questions, coach and principal surveys asked questions about their school climate and their opinions about instructional coaching, the role of each participant, their skills related to instructional coaching, and the impact of instructional technology coaching on student engagement and learning. Nearly all coaches $(n=47)$ and principals $(n=45)$ completed both pre- and post-surveys (Table 1). We also surveyed district leads to understand the alignment of the DLP with their district goals and the possibility of sustaining and scaling the DLP in each district; 18 of the 20 districts responded to the survey.

Teacher surveys asked participating teachers to agree or disagree with statements on teacher use of technology, principal-coach-teacher partnership, coach-teacher collaboration, school culture, job satisfaction, and student engagement and learning. Teacher surveys also included questions on demographics, amount of participation time in the DLP, and amount of support received from the coach. Eleven hundred $(1,100)$ DLP teachers completed the pre-survey and 855 DLP teachers completed the post-survey. Two hundred ninety-four teachers completed both surveys.

At the end of the year, we also surveyed teachers in the DLP schools who did not participate (Non-DLP teachers) in the program $(n=430)$ in order to compare their use of technology with that of DLP teachers.

Student perspective was also solicited twice per year. Pre- and post-surveys were administered to students of four case study teachers (please see "Qualitative Data Collection" section). These surveys were designed to measure the ultimate impact of coaching on student engagement and use of technology.

Table 1. Number of teachers, principals, coaches, and students who completed surveys

\begin{tabular}{|l|l|l|l|l|l|}
\hline Survey & DLP Teachers & $\begin{array}{l}\text { Non-DLP } \\
\text { Teachers }\end{array}$ & Coaches & Principals & $\begin{array}{l}\text { Case study } \\
\text { students }\end{array}$ \\
\hline Pre-survey & 1100 & N/A & 50 & 50 & 1668 \\
\hline Post-survey & 855 & 430 & 47 & 45 & 1105 \\
\hline $\begin{array}{l}\text { Matched } \\
\text { pre and post } \\
\text { surveys }\end{array}$ & 294 & N/A & 47 & 45 & 798 \\
\hline
\end{tabular}




\section{Qualitative Data Collection}

We selected four volunteer case study schools to participate in more extensive data collection. In selecting the four schools, we identified schools that represented the diversity of the project in geographic region, socioeconomic status, access to technology, and school size.

At each case study school, we conducted three site visits throughout the year (at the beginning, in the middle, and at the end of the school year). During each visit, in each school, we interviewed principals, coaches, and three to seven volunteer teachers who received coaching throughout the entirety of the school year. Case study teachers taught a variety of subjects at different grade levels. The interviews were semi-structured around the following main thematic areas: implementation of coaching in schools, respondent's role in instructional technology coaching, respondent's understanding of the coach-teacher-principal partnership, and impact of coaching.

In addition to interviews, we also observed case study teachers during one class period of instruction teaching on their own (in visits one and three), and while working with their coach (in visit two). During observations, we took descriptive notes on how teachers used technology.

We also interviewed four of the program mentors. Conducted at the end of the school year, these semi-structured interviews asked mentors to reflect on changes in technology use over time, and qualities of successful instructional coaching.

\section{Data Analysis}

\section{Quantitative Data Analysis}

Quantitative data analysis included both descriptive and inferential analysis (using SPSS). Descriptive analysis was run on all the variables to understand data trends at the beginning and at the end of the year. Additional analysis was run to analyze changes between the beginning of the year and the end of the year in: 1) DLP teachers' perception of the power of instructional technology coaching in fostering student learning and/or engagement; 2) DLP teachers' agreement on the openness of school culture in terms of risk-taking; 3) coaches' coaching skills; and 4) principals' leadership skills in instructional technology coaching. Table 2 presents the results of this analysis.

Table 2 - Paired samples t-test results (DLP participants - beginning of year versus end of year)

\begin{tabular}{|l|l|l|l|}
\hline Variable & $\begin{array}{l}\text { Mean - beginning of } \\
\text { year }\end{array}$ & Mean - end of year & Statistical Significance \\
\hline $\begin{array}{l}\text { Teacher perception } \\
\text { about coaching and } \\
\text { student engagement }\end{array}$ & $M=4.2, S D=.88$ & $M=4.4, S D=.69$ & $\begin{array}{l}p<.001, \text { Wilcoxon Signed- } \\
\text { ranks test, } Z=3.672, r=.2\end{array}$ \\
\hline $\begin{array}{l}\text { Teacher perception } \\
\text { about coaching and } \\
\text { student learning }\end{array}$ & $M=4.2, S D=.83$ & $M=4.4, S D=.71$ & $\begin{array}{l}p<.001, \text { Wilcoxon Signed- } \\
\text { ranks test, } Z=3.799, r=.2\end{array}$ \\
\hline $\begin{array}{l}\text { DLP teacher } \\
\text { agreement on the } \\
\text { openness of school } \\
\text { culture in terms of } \\
\text { risk-taking }\end{array}$ & $M=4.1, S D=.90$ & $M=4.3, S D=.80$ & $\begin{array}{l}p<.05, \text { Wilcoxon Signed- } \\
\text { ranks test, } Z=3.148, r=.2\end{array}$ \\
\hline $\begin{array}{l}\text { Coaches coaching } \\
\text { skills }\end{array}$ & $M=3.7, S D=.63$ & $M=4.1, S D=.62$ & $\begin{array}{l}p<.001, \text { Wilcoxon Signed- } \\
\text { ranks test, } Z=3.509, r=.5\end{array}$ \\
\hline
\end{tabular}




\begin{tabular}{|l|l|l|l|}
\hline $\begin{array}{l}\text { Principals leadership } \\
\text { skills in coaching }\end{array}$ & $M=3.6, S D=.61$ & $M=4.1, S D=.49$ & $\begin{array}{l}p<.001 \text {, Wilcoxon Signed- } \\
\text { ranks test, } Z=4.153, r=0.7\end{array}$ \\
\hline $\begin{array}{l}\text { Student use of } \\
\text { technology for } \\
\text { collaboration }\end{array}$ & $M=3.3, S D=1.31$ & $M=3.4, S D=1.24$ & $\begin{array}{l}p<.05, \text { paired sample } t \text {-test, } \\
r=0.168\end{array}$ \\
\hline $\begin{array}{l}\text { Student use of } \\
\text { technology for } \\
\text { critical thinking }\end{array}$ & $M=2.9, S D=1.37$ & $M=3.0, S D=1.40$ & $\begin{array}{l}p<.05, \text { paired sample } t \text {-test, } \\
r=0.142\end{array}$ \\
\hline $\begin{array}{l}\text { Student use of } \\
\text { technology for } \\
\text { communication }\end{array}$ & $M=2.9, S D=1.50$ & $M=3.0, S D=1.37$ & $\begin{array}{l}p<.001, \text { paired sample } \\
t \text {-test, } r=0.218\end{array}$ \\
\hline $\begin{array}{l}\text { Student use of } \\
\text { technology for } \\
\text { agency }\end{array}$ & $M=3.3, S D=1.47$ & $M=3.6, S D=1.40$ & $\begin{array}{l}p<.001 \text {, paired sample } \\
t \text {-test, } r=0.163\end{array}$ \\
\hline
\end{tabular}

Independent samples t-tests were performed to analyze differences between DLP teachers and non-DLP teachers at the end of the year in terms of: 1) their frequency of use of technology during the school year; 2) their quality of use of technology; 3 ) their job satisfaction; and 4) their perception of school culture in terms of collaboration and risk taking. We used several questions to measure teacher quality of use of technology. While it made sense to ask some of the questions for both DLP and non-DLP teachers, we couldn't ask others (e.g., the six indicators of Powerful Use of Technology) from non-DLP teachers because responding to those questions required training and participation in the DLP. For those questions, our analysis was limited to a descriptive level. Table 3 presents the results of this analysis.

Table 3 - Independent samples t-tests (DLP versus Non DLP):

\begin{tabular}{|l|l|l|l|}
\hline Variable & $\begin{array}{l}\text { DLP teachers - mean, } \\
\text { standard deviation }\end{array}$ & $\begin{array}{l}\text { Non-DLP teachers } \\
- \text { mean, standard } \\
\text { deviation }\end{array}$ & Statistical Significance \\
\hline $\begin{array}{l}\text { Difference in } \\
\text { frequency of use of } \\
\text { technology }\end{array}$ & $M=4.29, S D=1.11$ & $M=4.03, S D=.90$ & $\begin{array}{l}p<.001, t=5.1, d= \\
1203\end{array}$ \\
\hline $\begin{array}{l}\text { Difference in general } \\
\text { progress in use of } \\
\text { technology in teaching } \\
\text { practice }\end{array}$ & $M=3.65, S D=1.11$ & $M=3.39, S D=1.05$ & $\begin{array}{l}p<.001, t=3.8, d= \\
1207\end{array}$ \\
\hline $\begin{array}{l}\text { Difference in use of } \\
\text { technology for con- } \\
\text { tent: DLP teachers vs } \\
\text { non-DLP teachers }\end{array}$ & $M=3.61, S D=1.10$ & $M=3.36, S D=1.06$ & $\begin{array}{l}p<.001, t=3.7, d= \\
1208\end{array}$ \\
\hline
\end{tabular}




\begin{tabular}{|l|l|l|l|}
\hline $\begin{array}{l}\text { Difference in use of } \\
\text { technology for peda- } \\
\text { gogy: DLP teachers vs } \\
\text { non-DLP teachers }\end{array}$ & $M=3.54, \mathrm{SD}=1.13$ & $M=3.31, \mathrm{SD}=1.03$ & $\begin{array}{l}p<.001, t=3.5, d= \\
834.3\end{array}$ \\
\hline $\begin{array}{l}\text { Teacher agreement on } \\
\text { the openness of school } \\
\text { culture in terms of } \\
\text { risk-taking }\end{array}$ & $M=4.2, \mathrm{SD}=0.93$ & $M=4.02, \mathrm{SD}=.89$ & $\begin{array}{l}p<.05, t=3.1, d= \\
835.4\end{array}$ \\
\hline
\end{tabular}

At the end, we conducted correlation analysis between our variables measuring quality of teacher technology use (dependent variables) and our demographic and participation variables. Table 4 presents the results of this analysis. 
Table 4 - Correlations

\begin{tabular}{|c|c|c|}
\hline Variable 1 & Variable 2 & Correlation \\
\hline $\begin{array}{l}\text { Level of support received from } \\
\text { the coach }\end{array}$ & $\begin{array}{l}\text { General satisfaction of being a } \\
\text { teacher at their school }\end{array}$ & $\begin{array}{l}\text { Positively correlated, Spearman's } \\
r=.2, p<.001\end{array}$ \\
\hline $\begin{array}{l}\text { Teacher agreement that coach } \\
\text { communicated in a non- } \\
\text { evaluative way }\end{array}$ & $\begin{array}{l}\text { General progress in using } \\
\text { technology to teach specific } \\
\text { content knowledge }\end{array}$ & $\begin{array}{l}\text { Positively correlated, Spearman's } \\
r=.4, p<.000\end{array}$ \\
\hline $\begin{array}{l}\text { Teacher agreement that coach } \\
\text { communicated in a non- } \\
\text { evaluative way }\end{array}$ & $\begin{array}{l}\text { General progress in using } \\
\text { technology to improve teaching } \\
\text { approaches }\end{array}$ & $\begin{array}{l}\text { Positively correlated, Spearman's } \\
r=.3, p<.000\end{array}$ \\
\hline $\begin{array}{l}\text { Teacher willingness to participate } \\
\text { in the DLP }\end{array}$ & $\begin{array}{l}\text { Increase in frequency of use of } \\
\text { technology in classroom }\end{array}$ & $\begin{array}{l}\text { Positively correlated, Spearman's } \\
r=.2, p<.000\end{array}$ \\
\hline $\begin{array}{l}\text { Teacher willingness to participate } \\
\text { in the DLP }\end{array}$ & $\begin{array}{l}\text { Amount of time working with the } \\
\text { coach }\end{array}$ & $\begin{array}{l}\text { Positively correlated, Spearman's } \\
r=.3, p<.000\end{array}$ \\
\hline $\begin{array}{l}\text { Teacher willingness to participate } \\
\text { in the DLP }\end{array}$ & $\begin{array}{l}\text { Level of support received from } \\
\text { the coach }\end{array}$ & $\begin{array}{l}\text { Positively correlated, Spearman's } \\
r=.3, p<.000\end{array}$ \\
\hline $\begin{array}{l}\text { Teacher willingness to participate } \\
\text { in the DLP }\end{array}$ & $\begin{array}{l}\text { Teacher agreement that coach } \\
\text { communicated in a non- } \\
\text { evaluative way }\end{array}$ & $\begin{array}{l}\text { Positively correlated, Spearman's } \\
r=.3, p<.000\end{array}$ \\
\hline $\begin{array}{l}\text { Number of cycles the teacher } \\
\text { participated in }\end{array}$ & $\begin{array}{l}\text { Teacher ability to actively engage } \\
\text { students with: } \\
\text { - selecting relevant technology } \\
\text { tools and resources for } \\
\text { learning; } \\
\text { - using technology to increase } \\
\text { collaboration with one another; } \\
\text { - using technology to increase } \\
\text { communication with one } \\
\text { another; } \\
\text { - using technology as a tool for } \\
\text { creativity and innovation skills. } \\
\text { - using technology as a tool for } \\
\text { critical thinking skills; } \\
\text { - using technology to develop } \\
\text { their agency. }\end{array}$ & $\begin{array}{l}\text { Positively correlated, Spearman's } \\
r=.2, p<.000\end{array}$ \\
\hline
\end{tabular}




\begin{tabular}{|l|l|l|}
\hline $\begin{array}{l}\text { Number of cycles the teacher } \\
\text { participated in }\end{array}$ & $\begin{array}{l}\text { General progress in using } \\
\text { technology to teach specific } \\
\text { content knowledge }\end{array}$ & $\begin{array}{l}\text { Positively correlated, Spearman's } \\
r=.3, p<.000\end{array}$ \\
\hline $\begin{array}{l}\text { Number of cycles the teacher } \\
\text { participated in }\end{array}$ & $\begin{array}{l}\text { General progress in using } \\
\text { technology to improve teaching } \\
\text { approaches }\end{array}$ & $\begin{array}{l}\text { Positively correlated, Spearman's } \\
r=.3, p<.000\end{array}$ \\
\hline
\end{tabular}

When reading the report, it is important to keep in mind the limitations of the data sources, which rely on the self-reports of stakeholders who voluntarily participated. We had no independent means of verifying the accuracy of their responses, which limits generalizability. Further, all schools who participated in the study received coaching; therefore, we could not examine differences between participating school and non-participating schools, and were limited to examining change over time. In addition, the number of matched teacher survey responses for the pre-survey and post-survey $(n=294)$ is relatively small compared to the number of responses for the pre-survey ( $\mathrm{n}$ $=1,110)$ or the post-survey $(n=855)$. The main reason for the limited number of linked pre-post responses is that the population of teachers asked to complete the pre-survey was different from the population of teachers asked to complete the post survey; the pre-survey was administered to teachers who, at the beginning of the year, had thought they might work with their coach at some point during the school year (instead of all teachers), and the post-survey was completed by teachers who received coaching at some point during the year.

Throughout this report, we used a holistic approach when deciding what information to present. We focused on presenting meaningful evidence of impact (over time among DLP teachers) or difference (between DLP and non-DLP teachers). Where we were able to perform tests of statistical significance we used those results to guide our decisions about what material to present. In some cases, we describe differences that were not statistically significant but were large in magnitude.

\section{Qualitative Data Analysis}

After each case study visit, we conducted a cross-sectional analysis of interview data. We analyzed interview transcripts using Dedoose, a cross-platform software package for analyzing qualitative data that allows researchers to code text, record memos, and analyze emergent themes. Preliminary codes falling into three categories of implementation, outcomes, and impacts were drawn deductively from our theory of change, and then adapted and extended after each visit as new themes emerged in the data. Our final complex coding scheme included 74 codes.

During the exploratory coding process, researchers read and re-read interview transcripts, selecting excerpts of text that were consistent with the themes identified in the coding scheme. Multiple coding passes were conducted to filter and focus features of the data relevant to the research questions. Researchers met during the coding process to compare their application of the coding scheme, conduct reliability checks, and develop the coding scheme.

Following at least two coding passes, researchers used coded excerpts to create cross-sectional thematic profiles for each school that compared and synthesized coach, principal, and teacher perspectives within each school during each visit (Table 5). Next, longitudinal thematic profiles were created for each school describing changes and continuities between the participant perspectives in the first, second, and third visits. Finally, we developed profiles for each theme that compared the trajectory of each school over time and compared participant perspectives across schools. Mentor interviews were coded using the same coding scheme and then thematic profiles were created representing the mentor perspective. Researchers met to discuss interpretations in each profile and produced memos on connections between themes. 
Table 5. Themes for cross-sectional school profiles

\begin{tabular}{|c|c|}
\hline \multirow[t]{4}{*}{ Implementation } & Mentor support to coaches and principals \\
\hline & Principal support to coaches and teachers \\
\hline & Coach support to teachers \\
\hline & Sustainability \\
\hline \multirow[t]{3}{*}{ Outcomes } & Coaches' instructional coaching skills \\
\hline & Principal leadership skills related to instructional coaching \\
\hline & Teacher job satisfaction \\
\hline \multirow[t]{4}{*}{ Impacts } & Impact of the DLP on teachers \\
\hline & Impact of the DLP on students \\
\hline & Impact of the DLP on school culture \\
\hline & Impact of the DLP on parents/community \\
\hline
\end{tabular}




\section{Appendix 2}

\section{Materials provided to coaches}

\begin{tabular}{|c|c|}
\hline Book study & $\begin{array}{l}\text { Over the course of the first eight weeks of the school year (Cycle 1), } \\
\text { coaches participated in a book study and completed weekly reflections. } \\
\text { The focus of the book study was: Magiera, J. (2017). Courageous edven- } \\
\text { tures: Navigating obstacles to discover classroom innovation. Thousand } \\
\text { Oaks, CA: Corwin, a SAGE Publishing Company. }\end{array}$ \\
\hline DLP Coach Training Series & $\begin{array}{l}\text { Throughout the course of the year, coaches participated in one or two } \\
\text { YouTube live sessions each month. Sessions that were led by mentors } \\
\text { and supplemented by companion resources covered the following } \\
\text { topics: } \\
\text { 1. Coaching Conversation Toolkit: Communication etiquette, the art of } \\
\text { asking questions and the 1:1 meeting cycle } \\
\text { 2. Real-time Coaching: Modeling, observations and real-time feedback } \\
\text { 3. Shifting to Adult Learning: Coaching the whole person } \\
\text { 4. Building an Innovative School Culture } \\
\text { 5. Digital Classroom Management: Setting up schools and classrooms } \\
\text { up for digital success } \\
\text { 6. Powerful Reflection: Using reflection-not evaluation-to learn and } \\
\text { grow } \\
\text { 7. Teaching Teachers: Designing and delivering effective professional } \\
\text { learning } \\
\text { 8. Creating Custom Resources for Teachers } \\
\text { 9. Building and Cultivating my PLN }\end{array}$ \\
\hline Coach newsletters & $\begin{array}{l}\text { Sent weekly. These included a checklist of program expectations, news } \\
\text { and updates, a tech tip of the week, and a \#DLPShoutout of the week } \\
\text { highlighting the efforts of an individual coach. }\end{array}$ \\
\hline
\end{tabular}




\begin{tabular}{|c|c|}
\hline Coaching tools & $\begin{array}{l}\text { A "Challenge Menu" with suggested challenge categories and associ- } \\
\text { ated strategies was provided to coaches. } \\
\text { During the first three cycles, coaches maintained logs of their } \\
\text { classroom visits, meetings, and progress of coached teachers in the } \\
\text { following formats: } \\
\text { - Teacher Tracker (Google sheet) } \\
\text { - Coaches maintained a list of coached teachers which included } \\
\text { demographic information. } \\
\text { - Teacher Innovation Plan (Google doc) } \\
\text {-Coaches documented each teacher's selected challenge, tracked } \\
\text { progress from 1:1 meetings. Coaches, and recorded end of cycle } \\
\text { reflections. } \\
\text { - Teacher Observation Forms (Google form) } \\
\text {-Coaches maintained records of their in-classroom support. } \\
\text { - Following Winter Institute, six observation tools were added. } \\
\text { During the fourth cycle, an online coaching dashboard started provid- } \\
\text { ing coaches with streamlined access to the logs }\end{array}$ \\
\hline
\end{tabular}

